\title{
Distribution of Trace Elements Controlled by Sector and Growth Zonings in Zircon from Feldspathic Pegmatites (Ilmen Mountains, the Southern Urals)
}

\author{
Ekaterina V. Levashova ${ }^{1}$, Sergey G. Skublov ${ }^{1,2, *}$ (I) and Vladimir A. Popov ${ }^{3}$ \\ 1 Institute of Precambrian Geology and Geochronology, Russian Academy of Sciences, nab. Makarova 2, \\ 199034 St. Petersburg, Russia; levashova.kateryna@yandex.ru \\ 2 Saint-Petersburg Mining University, 21st Line 2, 199106 St. Petersburg, Russia \\ 3 South Ural Federal Scientific Center for Mineralogy and Geoecology of the Ural Branch of the Russian \\ Academy of Sciences, Ilmensky Reserve, 454000 Miass, Russia; popov@mineralogy.ru \\ * Correspondence: skublov@yandex.ru; Tel.: +7-921-650-8570
}

check for updates

Citation: Levashova, E.V.; Skublov, S.G.; Popov, V.A. Distribution of Trace Elements Controlled by Sector and Growth Zonings in Zircon from Feldspathic Pegmatites (Ilmen Mountains, the Southern Urals). Geosciences 2021, 11, 7. https://doi. org/10.3390/geosciences 11010007

Received: 3 November 2020 Accepted: 23 December 2020 Published: 25 December 2020

Publisher's Note: MDPI stays neutral with regard to jurisdictional claims in published maps and institutional affiliations.

Copyright: () 2020 by the authors. Licensee MDPI, Basel, Switzerland. This article is an open access article distributed under the terms and conditions of the Creative Commons Attribution (CC BY) license (https: / / creativecommons.org/ licenses/by/4.0/).

\begin{abstract}
The present study contains the detailed ion microprobe data on trace and rare earth elements distribution in the large zircon crystal about $10 \times 6 \mathrm{~mm}$ in size with distinct growth and sector zonings from Ilmen Mountains feldspathic pegmatite. The zircon crystal morphology is a combination of a prism $\{110\}$ and a dipyramid $\{111\}$. It is found out that the growth sector of the prism $\{110\}$ generally contains higher concentrations of Th, U, REE, Y, and $\mathrm{Nb}$ and exhibits a more gently sloping HREE distribution pattern and a steeper LREE distribution pattern, in contrast to zircon from the growth sector of the dipyramid $\{111\}$ development. Such a sector zoning pattern was formed at a late stage in crystal growth, when the prism $\{110\}$ began to prevail over the dipyramid $\{111\}$. The zircon studied displays the growth zoning formed of alternating bands in back-scattered electron (BSE) image: wide dark and thin light bands. The last ones contain elevated Th, U, REE, Y, Nb, and Ti concentrations, Th/U ratio and $\mathrm{Ce} / \mathrm{Ce}^{*}$. This growth zoning is most probably due to simultaneous crystallization of other minerals that concentrate trace elements, e.g., apatite and monazite, and the lack of equilibrium between zircon and fluid (melt).
\end{abstract}

Keywords: zircon; crystal zoning; trace elements; REE; ion microprobe; Ilmen Mountains

\section{Introduction}

Numerous studies have been done on the heterogeneity of mineral crystals. They show that as crystals grow, all minerals attain a zonal-sectorial structure. Various authors assume that crystal sector zoning is due to a difference in "crystallization force", the relative growth rates of the faces of various forms, the ratio of crystal growth rate to element diffusion near the surface layer of the crystalline lattice [1,2], and a difference in cation adsorption on the face surface [3]. A difference in the growth mechanisms of the faces of various forms has been also assumed (e.g., [4]).

Many accessory minerals, e.g., apatite [5-9], titanite [10], fluorite [11], xenotime and florencite [12,13], zircon [14-17], and rock-forming minerals, e.g., calcite [18,19], orthopyroxene [20], clinopyroxene [21], and garnet [22], were shown to differ in trace and rare-earth element (REE) distribution within a crystal.

Zircon is a striking example of variation in mineral composition in various growth zones and sectors. The study of sector zoning in zircon has revealed 1.5-3.5-fold variations in $\mathrm{U}$ and Th concentrations and Th/U ratio, depending on a crystal form [23].

In accordance with images of cathodoluminescence (CL) and scanning electron microscopy (BSE) study, degree of color intensity of zircon sector zones clearly indicates difference in zone compositions in the growth sectors of dipyramid $\{111\}$ and prism $\{110\}$. According to [24], granitic melt with low $\mathrm{U}, \mathrm{Th}, \mathrm{Y}, \mathrm{REE}$, and $\mathrm{P}$ concentrations is responsible for crystallization of prism $\{100\}$ in comparison with that of prism $\{110\}$, and vice versa. 
The delayed growth of the faces of dipyramid $\{211\}$, in comparison with those of other forms, is probably due the adsorption of impurity elements on dipyramid faces.

Some authors (e.g., $[17,25,26])$ attribute the sector zoning of zircon to the composition, temperature, and cooling rate of parent melt. Another contributor is crystal growth rate: the fastest-growing sector is enriched in P but depleted in REE in contrast to the slowly growing sector (prism) [27]. A difference in $P$ and REE behavior is due to the ratios of these elements in zircon and co-existing melt: the melt is commonly richer in $\mathrm{P}$ than zircon but is poorer in REE. Therefore, P diffusion proceeds from the zircon surface into the melt, while REE diffusion proceeds from the melt toward a crystallizing zircon crystal. Eventually, diffusion limits the concentrations of these elements in growing zircon. The recent experimental study of zircon has shown that sector zoning causes significant dispersion in the population of zircon compositions even for those grown from a homogeneous melt [28].

Zircon from pegmatites, which is often big in size and displays a variety of consecutive oscillatory zoning and forms of crystals, is a good example for the study of zircon composition in the growth zones and sectors of the faces of various forms. Earlier studies of zircons from Uralian pegmatites, including those from the Ilmen Mountains, showed considerable variations in the compositions of trace elements (Hf, $\mathrm{REE}, \mathrm{Nb}$, and $\mathrm{Ta}$ ) that increase in concentration from early to middle generations and drop rapidly in the latest generation, except for Hf, whose concentration in zircon rises during the formation of pegmatite [29].

The early (internal) area of zircon crystals from Ilmen feldspathic pegmatite were found later to display elevated $\mathrm{U}, \mathrm{Th}, \mathrm{Sc}, \mathrm{Ta}, \mathrm{Y}$, and REE and low Hf concentrations, in contrast to peripheral area [30]. In this case, $\mathrm{Yb}$ concentration in the growth zone of prism $\{100\}$ tends to be higher than that in the growth zone of dipyramid $\{111\}$. However, no specifically focused studies of REE distribution relative to the sector zoning for Ilmen zircon by modern in situ methods have yet been undertaken.

The aim of this research is to identify the reason for the trace element variation in specific growth sector forms of zircon and its significance for geochronological studies.

\section{Geological Setting}

A coarse (about $10 \times 6 \mathrm{~mm}$ in size) zircon crystal from feldspathic pegmatite, sampled at the eastern exocontact of the Ilmen alkaline Southern Urals massif was used for study. The investigated crystal is the largest of all the selected zircons. In addition, in this crystal, the faces of crystallographic forms have received a distinct development and oscillatory zoning are clearly demonstrated, which made it possible to study it with a high degree of detail.

The Ilmenogorsk nepheline syenite massif, $18 \mathrm{~km}$ in length and $50 \mathrm{~km}^{2}$ in plain view, looking like a drop in plain view which increases in width southwards (Figure 1). The massif consists dominantly of banded biotite-K-feldspathic nepheline syenite (miaskite). Its marginal zones are composed of plagiomiaskite and plagiosyenite. Typical Ilmenogorsk miaskites are largely K-feldspathic rocks that contain $25-40 \%$ nepheline, $10-15 \%$ oligoclasealbite (nos. 10-15), 5-10\% biotite (annite), 1-3\% calcite and accessory ilmenite, titanite, zircon, pyrochlore, allanite-(Ce), fluorapatite, etc. [31]. Such miaskites make up $\sim 40 \%$ of the massif. Biotite-amphibole, amphibole and pyroxene-amphibole varieties also occur; plagiomiaskites and muscovitic, bimica, scapolitic and antiperthitic miaskites were reported more recently. The syenite exocontact zone of the massif is $\sim 50 \mathrm{~m}$ wide in the south and 400-600 $\mathrm{m}$ wide in the north; syenites alternate with fenites.

The Ilmenogorsk alkaline massif, especially its exocontact portion, exhibits early to late pegmatite fields of various ages: granitic pre-miaskitic $\rightarrow$ feldspathic (syenitic) $\rightarrow$ miaskitic $\rightarrow$ corundum-feldspathic $\rightarrow$ alkaline-ultramafic $\rightarrow$ carbonatitic $\rightarrow$ granitic post-miaskitic $\rightarrow$ granitic amazonitic [32]. 


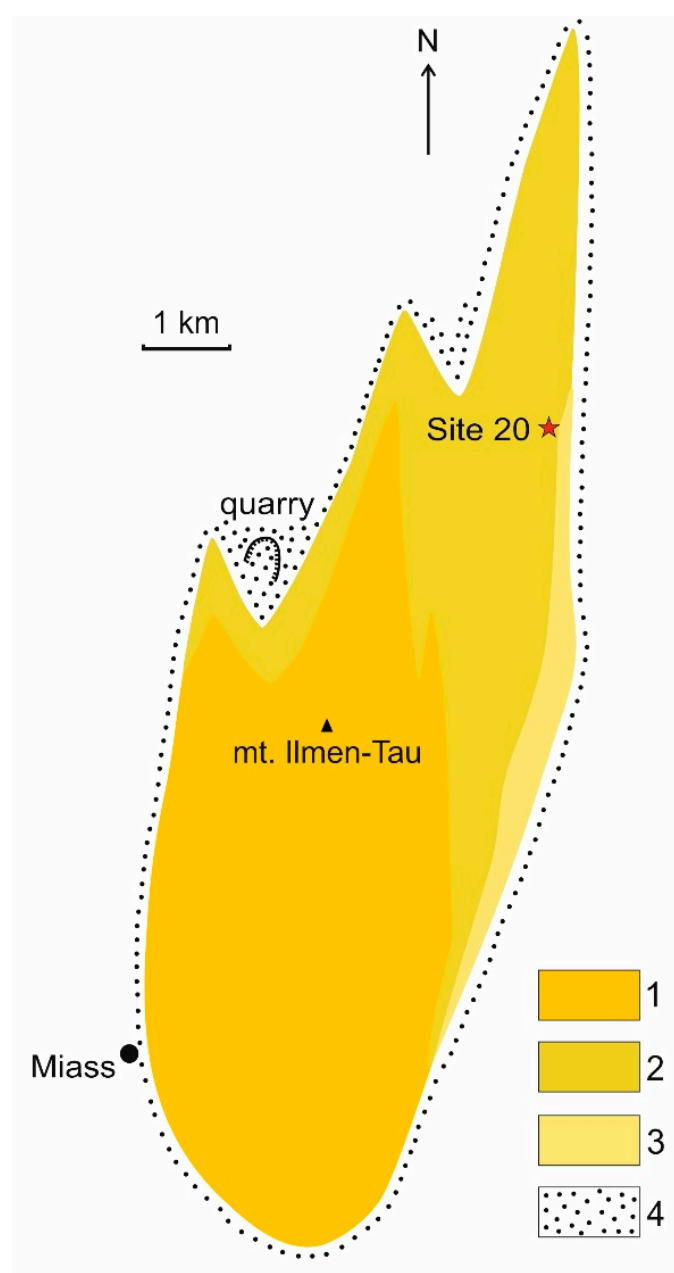

Figure 1. Sketch map of the Ilmenogorsk alkaline massif [33]: (1) central miaskite body; (2) eastern miaskite body; (3) northern framing of miaskite bodies and syenite zones; (4) alkaline metasomatites (fenites).

All types of pegmatite contain zircon, which is commonly polygenerational and displays various parageneses. As the shape, color, and size of zircon vary considerably, Ilmen pegmatites are considered favorable for various studies. Zircon from mica-feldspar pegmatites is large, up to $3 \mathrm{~cm}$ [30] columnar prismatic, dipyramidal-prismatic of yellowbrown and brown color. On a cut, zircon is often homogeneous, contrasting zonal-sectorial areas are observed during irradiation. Zircons from miaskite and syenite pegmatites are characterized by a brownish tint, subisometric appearance, dipyramidal-prismatic or dipyramidal habit, crystals up to $2 \mathrm{~cm}$ in size [30]. Preliminary data on the composition of zircons show that many of its constituents vary markedly [34,35]. Syntactic zircon-xenotime intergrowths are encountered. A single find of hafnon has been reported. Some green metamict zircons contain high uranium and thorium concentrations. In some pegmatites, pinacoid $\{001\}$ faces in zircon are well-developed and the crystals look like cubes. Some granitic pegmatites have many zones with very fine zircons, revealed only at considerable magnification. Of great interest are synchronous intergrowths of zircon with pyrochlore, xenotime, monazite, samarskite, ilmenorutile, columbite, garnet, magnetite, apatite, calcite, albite, amazonite, topaz, and other minerals. Such intergrowths are used to check whether available geothermometers and geobarometers are good enough for physico-chemical modeling of mineral formation.

To date, various results have been obtained for the dating of zircon from feldspar pegmatites of the Ilmenogorsk massif by the local U-Pb method (SHRIMP-II) - $240 \pm 5 \mathrm{Ma}$ [36]. A considerable variation in age from 231 to $282 \mathrm{Ma}$ was obtained by studying various min- 
erals of the Ilmen-Vishnevogorsk alkaline complex [37]. The U-Pb age of pyrochlores from miaskite-pegmatites was calculated to be $231 \pm 29 \mathrm{Ma}$ (TIMS), of zircons-279 $\pm 10 \mathrm{Ma}$ (SHRIMP II) and $282 \mathrm{Ma}$ (LA-ICP-MS). One more U-Pb age of zircon from feldspar pegmatites of the Ilmenogorsk massif is $273 \pm 14$ Ma (unpublished author' data by S.G. Skublov). Thus, the age of the feldspar pegmatites of the Ilmen Mountains can be estimated to fall within the interval of 230-280 Ma.

A zircon crystal from feldspathic pegmatite at site 20, in which pegmatitic aggregate consists of coarse microcline and albite-oligoclase and is locally intergrown with biotite and apatite, was analyzed in this study. Zircon occurs as coarse crystals in one of the late feldspar crystal zones throughout the entire pegmatite vein. Host rocks are represented by medium-grained aegirine and biotite syenites and fenites [31].

\section{Materials and Methods}

A coarse (about $10 \times 6 \mathrm{~mm}$ in size) zircon crystal from feldspathic pegmatite was collected at site 20 in the Ilmen Mountains to analyze the variable chemical composition of zircon in each growth zone and sector. The zircon used in our study was extracted following a standard method using heavy liquids from the sample of pegmatite. The prism $\{110\}$ and dipyramid $\{111\}$ faces in the zircon crystal are well-developed. The zircon preparation method employed is similar to the one described in [38]. The zircon crystal was cut along the elongation axis L4 [001], mounted onto standard epoxy mount. The central cross-section of the crystal was brought approximately onto the surface of the mount.

The major element composition of zircon was analyzed using the SEM-EDS method at the Institute of Precambrian Geology and Geochronology of Russian Academy of Sciences by a JEOL JSM-6510LA scanning electron microscope with a JED-2200 energy dispersal attachment (JEOL Ltd., Akishima, Japan). The internal structure of zircon was studied in a compositional contrast regime (back-scattered electrons, BSE). A polished sample was carbon-coated. Point determinations of mineral compositions were performed with an electron beam at an accelerating voltage of $20 \mathrm{kV}$ and a current of $1 \mathrm{nA}$; the point was $3 \mu \mathrm{m}$ in size. The accumulation time of each spectrum was $50 \mathrm{~s}$. Natural minerals, pure oxides, and metals were used as standards. ZAF algorithm was used for correction of a matrix effect. A total of 116 point analyses of zircon and 11 analyses of co-existing minerals were carried out for their identification. Analysis of zircon by the EDS method revealed no impurity elements, except for $\mathrm{Hf}$ and Th and one zircon point with $\mathrm{Al}$ and Fe impurity due to their low content (the detection limit for trace elements is $0.1 \mathrm{wt} . \%$ ). As Hf and Th concentrations were measured precisely by an ion microprobe, the analytical results obtained by the EDS method are not reported in the present paper. Zircon was studied by an electron microscope both prior to its analysis by an ion microprobe to mark the future craters relative to the particular portions of the growth sectors and growth zones of zircons and after analysis for the accurate tying of analytical craters to the internal structure of zircon.

Analysis of rare earth and trace elements in the zircons was carried out by secondaryion mass spectrometry on a Cameca IMS-4F ion microprobe (Cameca, Gennevilliers, France) at the Yaroslavl Branch of the Institute of Physics and Technology, Russian Academy of Sciences. Analytical procedures are mainly described in [39-42]. The primary $\mathrm{O}_{2}{ }^{-}$ion beam was accelerated to about $14.5 \mathrm{keV}$ and focused to a spot size of $\sim 20 \mu \mathrm{m}$. The ion current was 5-8 nA. Each analysis was carried from 3 cycles of measurements with a discrete transition between mass peaks within the given set of elements. The total measurement time of one point is on average about 30 minutes and varies depending on signal intensity and was determined automatically by statistical control. The absolute concentrations of each element were calculated from the measured intensities of positive atomic secondary ions, which were normalized to the intensity of secondary 30Si+ ions, using calibration curves based on a set of reference glasses [43,44]. NIST-610 reference glass [45] was used as a daily monitor for trace element analyses. The following isotopes were measured: ${ }^{7} \mathrm{Li}^{+},{ }^{29} \mathrm{Si}^{+},{ }^{31} \mathrm{P}^{+},{ }^{42} \mathrm{Ca}^{+},{ }^{49} \mathrm{Ti}^{+},{ }^{88} \mathrm{Sr}^{+},{ }^{93} \mathrm{Nb}^{+},{ }^{89} \mathrm{Y}^{+},{ }^{138} \mathrm{Ba}^{+},{ }^{139} \mathrm{La}^{+},{ }^{140} \mathrm{Ce}^{+},{ }^{141} \mathrm{Pr}^{+},{ }^{143} \mathrm{Nd}^{+}$, 
${ }^{149} \mathrm{Sm}^{+},{ }^{153} \mathrm{Eu}^{+},{ }^{154} \mathrm{Gd}^{+},{ }^{156} \mathrm{Gd}^{+},{ }^{158} \mathrm{Gd}^{+},{ }^{162} \mathrm{Dy},{ }^{163} \mathrm{Dy}^{+},{ }^{165} \mathrm{Ho}^{+},{ }^{167} \mathrm{Er}^{+},{ }^{174} \mathrm{Yb}^{+},{ }^{175} \mathrm{Lu}^{+}$, ${ }^{178} \mathrm{Hf}^{+},{ }^{232} \mathrm{Th}^{+},{ }^{238} \mathrm{U}^{+}$. Procedure of subtraction was used to correct the signals of ${ }^{31} \mathrm{P}^{+}$, ${ }^{88} \mathrm{Sr}^{+},{ }^{89} \mathrm{Y}^{+},{ }^{93} \mathrm{Nb}^{+},{ }^{138} \mathrm{Ba}^{+},{ }^{139} \mathrm{La}^{+},{ }^{140} \mathrm{Ce}^{+},{ }^{141} \mathrm{Pr}^{+},{ }^{153} \mathrm{Eu}^{+},{ }^{158} \mathrm{Gd}^{+},{ }^{174} \mathrm{Yb}^{+},{ }^{167} \mathrm{Er}^{+}$describe on $[39,41,42,46]$. Accuracy of the trace element measurements for most elements with a concentration $>1 \mathrm{ppm}$ is $10-15 \%$ and $15-20 \%$-for the concentration range $0.1-1 \mathrm{ppm}$; mean detection limit is $5-10 \mathrm{ppb}$.

To construct REE distribution spectra, the composition of zircon was normalized for that of chondrite CI [47]. Zircon crystallization temperature was estimated with a Ti-in-Zrn thermometer [48]. As no Ti-minerals in the feldspathic pegmatite sample analyzed were revealed, the estimate presented indicates a lower zircon formation temperature limit. The median value, most valid in an uncertain type of statistical distribution of data on zircon composition, was used as a mean value when discussing analytical data [49]. A total of 55 point analyses of trace and rare earth elements were carried out (Figure 2, Table S1), of which 22 points were placed within the growth sector of the prism $\{110\}, 33$ points are in the growth sector of the dipyramid $\{111\}$ (16 points are on one the face (111) and 17 points on the other face (1111). In this case, the analytical points form six profiles from the center to the margin of the crystal perpendicular to growth zoning. Three profiles are located within the prism and three within the dipyramid. A trace element distribution pattern in zircon in one growth zone can thus be compared, but in the growth sectors of various forms, on the one hand, and in various growth zones within each of forms presented, on the other.

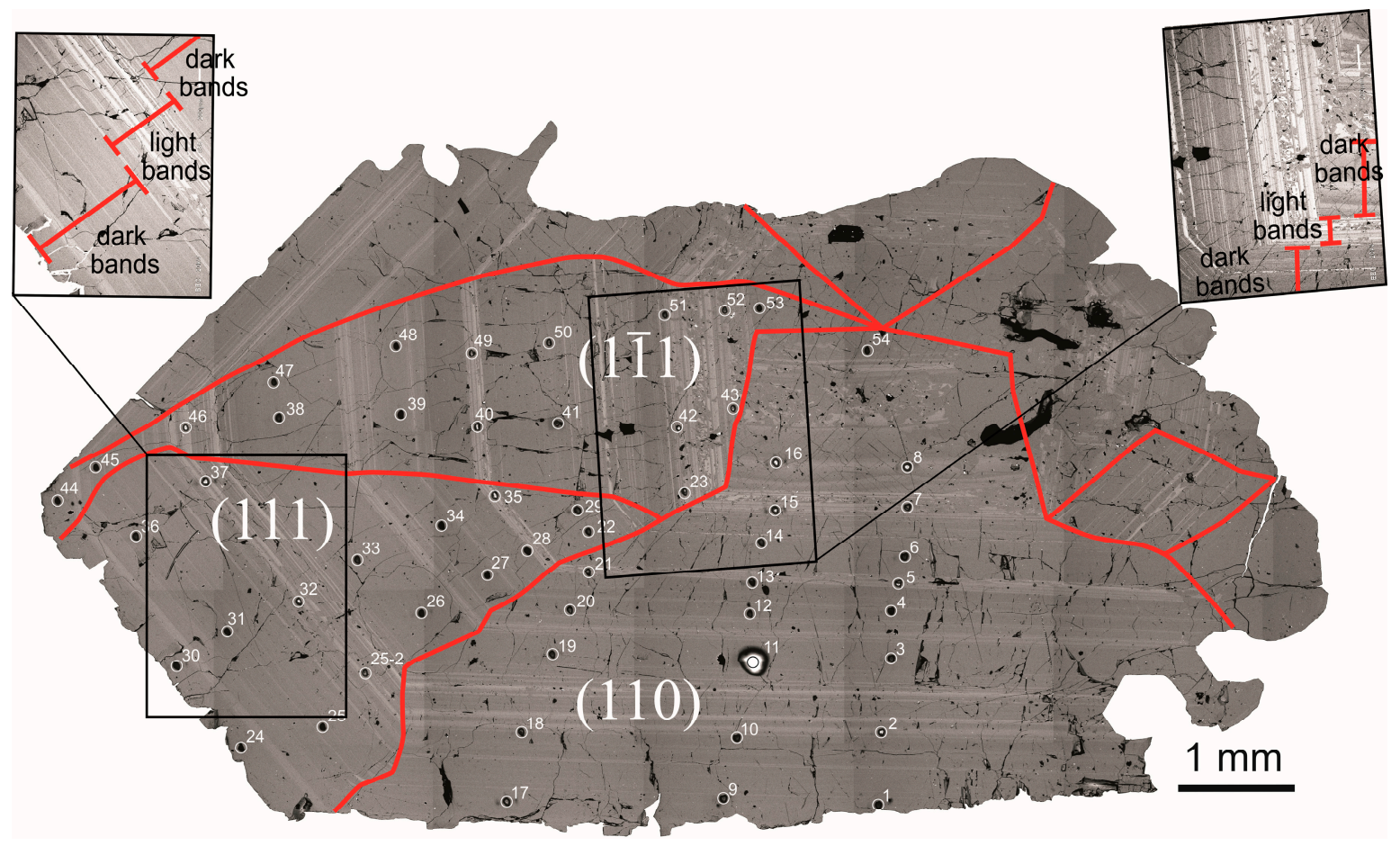

Figure 2. BSE image of zircon crystal from Ilmen Mountains feldspathic pegmatite. White circles encircle the craters of the ion microprobe, indicating the sequence number of analytical points. Red lines indicate the boundaries of growth sectors on the crystal.

\section{Results}

\subsection{Internal Zircon Structure}

The zircon crystal studied is intergrown with albite, K-feldspar, and apatite. The latter is $500 \mu \mathrm{m}$ in size in cross-section. Fine monazite grains within apatite were revealed. There are no other mineral phase inclusions found in the zircon crystal. One common internal structural feature of the crystal is the presence of thin bands that display a light 
color in a BSE-image. The bands resemble oscillatory growth zoning which often occurs in zircon and is typical of zircons of igneous origin [50]. The light bands are morphologically complex. They commonly vary in thickness from several microns to $10-20 \mu \mathrm{m}$. The light color varies in intensity over the entire band until it disappears completely. Sometimes they combine to form light bands up to $40-50 \mu \mathrm{m}$ in width. Light bands over the entire area of the crystal (from the center to the margin) form a thickening. There are five such thickening areas. The thickness of thickening areas of light-colored bands is variable from 200-650 $\mu \mathrm{m}$ (Figure 2). Between such thickening areas, there are darker zircon bands with either no or thin light bands. The dark bands are 500-700 $\mu \mathrm{m}$ thick. The internal structure of zircon can be subdivided into three parts.

Part I is the innermost portion of the crystal, which occupies about $15-20 \%$ of its entire cross-section along $\mathrm{L}_{4}$-axis. The growth sectors of the prism $\{110\}$ and dipyramid in the form of the face (111) are located in this portion. The face length of the prism is commensurable with that of the dipyramid and is slightly greater. A $200-300 \mu \mathrm{m}$ thick wide light band marks the external boundary of this portion. The band is thinner along the prism face than along the dipyramid face. The light band along the dipyramid face falls into two thicker monolithic light bands that rim the light band. There are brighter points within the light band which are due to the formation of a coarse sculpture on the faces during the growth. The integrity of the thin light bands is occasionally destroyed, and their fragments form irregular aggregates and clusters. The arbitrary boundary of the first portion of zircon is traced by analytical points 7, 15, 23, 42, and 51 (Figure 2, Table S1).

The second portion of zircon occupies an intermediate position in the crystal and comprises two dark bands separated by a relatively thin (up to $20 \mu \mathrm{m}$ ) light band which is more distinct in the growth sector of the dipyramid. The light band, which is external for this portion, is up to $80 \mu \mathrm{m}$ thick in the dipyramid sector and no more than $50 \mu \mathrm{m}$ in the prism sector. A remarkable feature of the second portion is that the face (1111) of the dipyramid $\{111\}$ was formed from zero and eventually became about $1 \mathrm{~mm}$ long. The length of the face (111) of the dipyramid $\{111\}$ varies slightly within this portion up to about $2 \mathrm{~mm}$. The area of the second portion of zircon is slightly greater than that of the internal portion. Both make up about $40 \%$ of the total area of the zircon crystal. The positions of analytical points $5,13,21,28,35,40$, and 49 are referenced against the boundary of the second portion of zircon (Figure 2, Table S1).

The suppression of the face (1111) and the considerable increase of the face (111) of the dipyramid $\{111\}$ are typical of the third, external, portion of zircon which occupies over $\frac{1}{2}$ of the crystal. Toward the crystal edge, the face length of the crystallographic form of the dipyramid, estimated from the length of the light bands, is no more than $150 \mu \mathrm{m}$ for (111) and about $4 \mathrm{~mm}$ for (1111). The length of the face (110) of the prism is up to $8 \mathrm{~mm}$. The intensity of the light bands in the third portion of zircon decreases and the thickness of the dark portions of zircon increases to $800 \mu \mathrm{m}$.

\subsection{General REE Distribution Pattern}

The total REE concentration in zircon varies from 120 to $2300 \mathrm{ppm}$, averaging about $400 \mathrm{ppm}$. The REE distribution spectra in the zircon studied are shown in Figure 3a. Interestingly, the individual spectra are absolutely parallel to each other. Only at points 5 and 7 (Figure 2) LREE ( $\mathrm{La}, \mathrm{Ce}, \mathrm{Pr}, \mathrm{Nd}$ ), especially La and Ce, concentrations are markedly higher, with the $\mathrm{Sm}_{\mathrm{N}} / \mathrm{La}_{\mathrm{N}}$ ratio of less than 1 (0.55 and 0.17, respectively, Table S1), which is not typical of zircon (Figure 3a). In the MREE (Sm, Eu) and HREE (Gd-Lu), the spectra for these points coincide with other spectra, suggesting that the elevated LREE concentration is due to apatite (LREE concentrating mineral) microinclusions which penetrate into the analytical field and are indiscernible in BSE. This assumption is favored by slightly elevated Ca and $P$ concentrations at these points. 


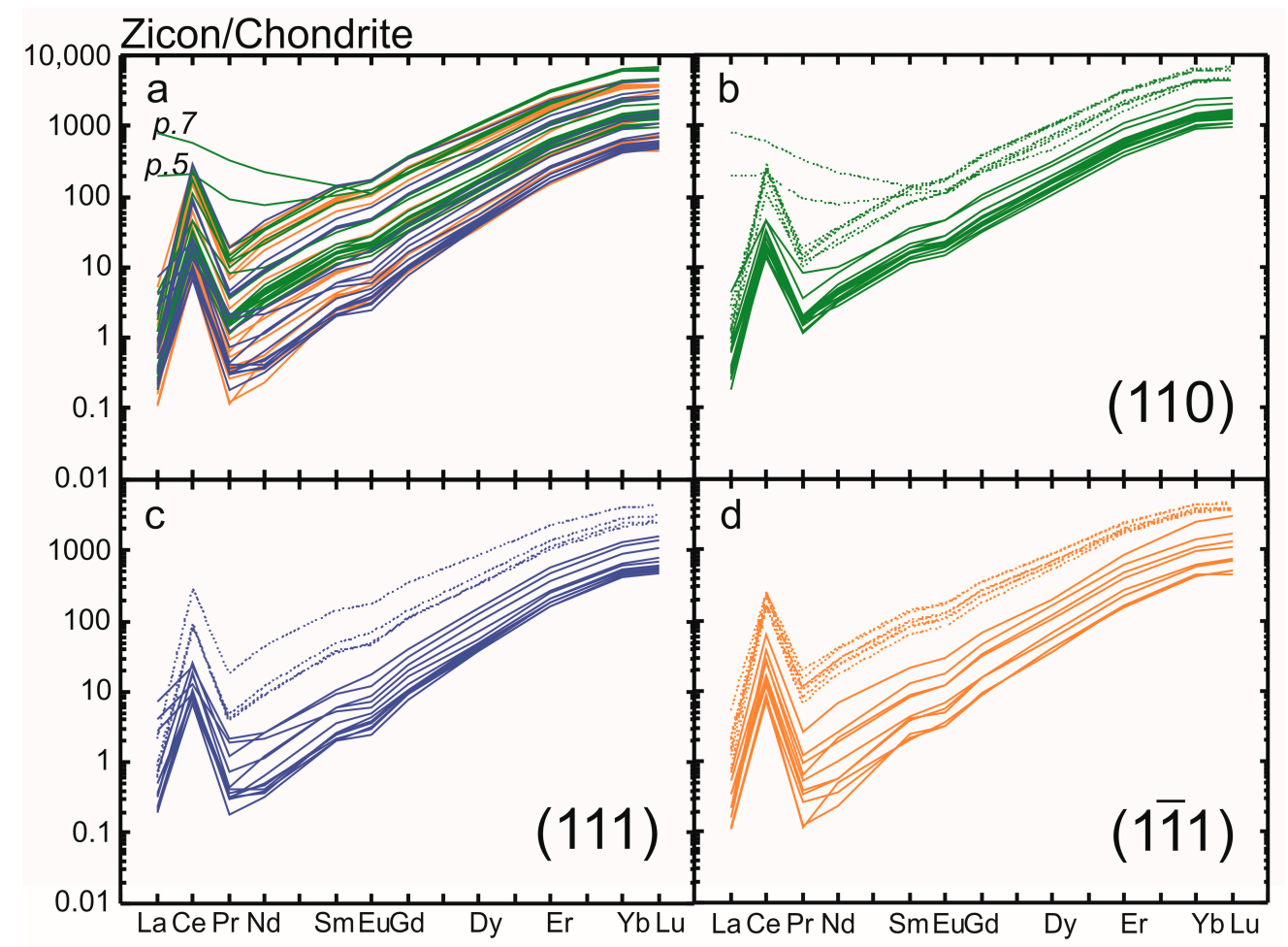

Figure 3. REE distribution spectra in zircon: (a) all points; (b) points of the prism face (110); (c) points of the dipyramid face (111); (d) points of the dipyramid face (1111). The dotted line (b-d) shows the compositions of the zircon areas which is light in BSE.

The REE distribution spectra exhibit a well-defined positive Ce-anomaly $\left(\mathrm{Ce} / \mathrm{Ce}^{*}\right.$ averages 30.0 for dark zircon portions and 45.9 for light portions, Table 1) and a poorlydefined Eu-anomaly (Eu/Eu* averages 0.8 , regardless of the type of zircon). Their common feature is a differentiated LREE to HREE distribution pattern common for zircon [51]. The REE distribution trend in zircon from feldspathic pegmatite is generally similar to that in zircon from the carbonatites and miaskites of the Ilmen-Vishnevogorsk alkaline complex [52].

Table 1. The mean (median) values of composition ( $\mathrm{ppm}$ ) of the zircon from Ilmen Mountains feldspathic pegmatite.

\begin{tabular}{|c|c|c|c|c|c|c|c|c|c|c|}
\hline & \multicolumn{5}{|c|}{ Dark Color } & \multicolumn{5}{|c|}{ Light Color } \\
\hline & Prism & Dipyramid & (111) & $(1 \overline{1} 1)$ & $\begin{array}{c}\text { All } \\
\text { Points }\end{array}$ & Prism & Dipyramid & (111) & $(1 \overline{1} 1)$ & $\begin{array}{c}\text { All } \\
\text { Points }\end{array}$ \\
\hline & $\mathbf{n}=\mathbf{1 5}$ & $\mathrm{n}=22$ & $\mathrm{n}=12$ & $\mathrm{n}=10$ & $\mathrm{n}=37$ & $\mathrm{n}=7$ & $\mathrm{n}=\mathbf{1 1}$ & $\mathrm{n}=4$ & $\mathrm{n}=7$ & $\mathrm{n}=\mathbf{1 8}$ \\
\hline $\mathrm{La}$ & 0.09 & 0.08 & 0.08 & 0.05 & 0.08 & 0.42 & 0.36 & 0.18 & 0.49 & 0.39 \\
\hline $\mathrm{Ce}$ & 12.9 & 7.68 & 6.44 & 9.59 & 11.0 & 149 & 102 & 55.5 & 132 & 130 \\
\hline $\operatorname{Pr}$ & 0.17 & 0.04 & 0.04 & 0.04 & 0.11 & 1.35 & 0.94 & 0.41 & 1.05 & 1.08 \\
\hline $\mathrm{Nd}$ & 1.90 & 0.29 & 0.26 & 0.36 & 1.18 & 16.1 & 11.0 & 4.91 & 13.0 & 13.0 \\
\hline $\mathrm{Sm}$ & 2.38 & 0.59 & 0.46 & 0.63 & 1.37 & 18.1 & 12.4 & 6.48 & 13.8 & 14.4 \\
\hline $\mathrm{Eu}$ & 1.25 & 0.30 & 0.26 & 0.35 & 0.69 & 6.92 & 6.06 & 3.34 & 6.98 & 6.65 \\
\hline $\mathrm{Gd}$ & 9.82 & 3.09 & 2.32 & 3.17 & 6.37 & 49.3 & 44.2 & 25.3 & 51.9 & 47.6 \\
\hline Dy & 39.0 & 13.5 & 12.2 & 15.3 & 28.9 & 186 & 156 & 97.6 & 172 & 172 \\
\hline $\mathrm{Er}$ & 89.9 & 35.4 & 33.2 & 39.2 & 68.6 & 357 & 302 & 204 & 309 & 327 \\
\hline $\mathrm{Yb}$ & 207 & 94.3 & 84.0 & 97.4 & 159 & 719 & 568 & 427 & 585 & 667 \\
\hline $\mathrm{Lu}$ & 35.7 & 16.9 & 15.1 & 17.5 & 27.3 & 116 & 94.0 & 71.0 & 94.8 & 108 \\
\hline $\mathrm{Li}$ & 0.04 & 0.03 & 0.03 & 0.04 & 0.04 & 0.12 & 0.18 & 0.12 & 0.20 & 0.13 \\
\hline $\mathrm{P}$ & 66.1 & 58.4 & 25.3 & 78.0 & 44.7 & 60.0 & 56.2 & 49.8 & 83.8 & 58.1 \\
\hline $\mathrm{Ca}$ & 28.4 & 24.5 & 24.4 & 27.5 & 25.4 & 29.7 & 31.8 & 25.6 & 38.3 & 30.7 \\
\hline $\mathrm{Ti}$ & 4.12 & 3.37 & 3.37 & 3.33 & 3.84 & 12.0 & 16.0 & 12.4 & 16.9 & 13.4 \\
\hline $\mathrm{Sr}$ & 0.82 & 0.84 & 0.78 & 0.86 & 0.83 & 1.23 & 1.17 & 0.95 & 1.36 & 1.20 \\
\hline
\end{tabular}


Table 1. Cont.

\begin{tabular}{|c|c|c|c|c|c|c|c|c|c|c|}
\hline & \multicolumn{5}{|c|}{ Dark Color } & \multicolumn{5}{|c|}{ Light Color } \\
\hline & Prism & Dipyramid & (111) & (1̄11) & $\begin{array}{c}\text { All } \\
\text { Points }\end{array}$ & Prism & Dipyramid & (111) & (11̄1) & $\begin{array}{c}\text { All } \\
\text { Points }\end{array}$ \\
\hline & $\mathrm{n}=15$ & $n=22$ & $n=12$ & $n=10$ & $\mathbf{n}=37$ & $\mathrm{n}=7$ & $n=11$ & $n=4$ & $\mathbf{n}=7$ & $\mathrm{n}=18$ \\
\hline$Y$ & 458 & 174 & 163 & 199 & 335 & 1945 & 1718 & 1104 & 1831 & 1850 \\
\hline $\mathrm{Nb}$ & 82.6 & 25.2 & 24.2 & 26.4 & 40.9 & 364 & 491 & 220 & 568 & 462 \\
\hline $\mathrm{Ba}$ & 1.91 & 1.76 & 1.70 & 1.79 & 1.78 & 2.18 & 2.36 & 2.10 & 2.65 & 2.35 \\
\hline Hf & 6867 & 7063 & 7124 & 7054 & 7004 & 6918 & 7381 & 7323 & 7381 & 7284 \\
\hline Th & 134 & 68.4 & 45.3 & 85.3 & 98.7 & 1479 & 2385 & 1075 & 2569 & 2043 \\
\hline $\mathrm{U}$ & 60.0 & 33.9 & 28.7 & 37.2 & 48.6 & 220 & 235 & 236 & 183 & 220 \\
\hline $\mathrm{Th} / \mathrm{U}$ & 2.02 & 1.90 & 1.55 & 2.17 & 1.96 & 7.11 & 9.52 & 4.55 & 12.0 & 9.46 \\
\hline $\mathrm{Eu} / \mathrm{Eu}^{*}$ & 0.78 & 0.73 & 0.72 & 0.74 & 0.76 & 0.79 & 0.79 & 0.79 & 0.79 & 0.79 \\
\hline $\mathrm{Ce} / \mathrm{Ce}^{*}$ & 26.4 & 38.5 & 24.8 & 47.6 & 29.9 & 34.0 & 46.0 & 47.4 & 43.5 & 45.9 \\
\hline$\Sigma \mathrm{REE}$ & 405 & 173 & 154 & 184 & 304 & 1915 & 1291 & 893 & 1382 & 1507 \\
\hline$\Sigma$ LREE & 15.0 & 8.52 & 6.75 & 10.1 & 12.0 & 168 & 113 & 60.3 & 147 & 152 \\
\hline$\Sigma$ HREE & 382 & 164 & 147 & 173 & 291 & 1428 & 1160 & 825 & 1214 & 1302 \\
\hline $\mathrm{Lu}_{\mathrm{N}} / \mathrm{La}_{\mathrm{N}}$ & 3128 & 2559 & 2318 & 4041 & 2634 & 3605 & 2609 & 3470 & 2136 & 2784 \\
\hline $\mathrm{Lu}_{\mathrm{N}} / \mathrm{Gd}_{\mathrm{N}}$ & 29.1 & 47.0 & 51.9 & 44.9 & 40.5 & 19.0 & 16.5 & 22.3 & 15.3 & 17.8 \\
\hline $\mathrm{Sm}_{\mathrm{N}} / \mathrm{La}_{\mathrm{N}}$ & 38.1 & 14.9 & 10.8 & 18.9 & 19.0 & 78.0 & 61.0 & 63.4 & 61.0 & 63.7 \\
\hline $\mathrm{T}(\mathrm{Ti}),{ }^{\circ} \mathrm{C}$ & 670 & 655 & 655 & 654 & 665 & 760 & 786 & 762 & 791 & 769 \\
\hline
\end{tabular}

The zircon portions, dark and light in BSE, differ considerably from each other in total REE concentration (about 1500 and $300 \mathrm{ppm}$, respectively). This difference is traceable on individual plots for each form (Figure 3b-d): REE spectra for light zircon portions are not overlapped by REE spectra for the dark portions of zircon. REE spectra for light zircon portions are generally less differentiated in the HREE region than those for dark portions $\left(\mathrm{Lu}_{\mathrm{N}} / \mathrm{Gd}_{\mathrm{N}}\right.$ ratio averages 18 and 41 , respectively) and are steeper in the LREE region $\left(\mathrm{Sm}_{\mathrm{N}} / \mathrm{La}_{\mathrm{N}}\right.$ ratio averages 64 and 19, respectively).

The zircon portions, light and dark in BSE, also differ markedly from each other (Table 1) in Ti concentration (13 and 4 ppm, respectively), Y (1850 and $335 \mathrm{ppm}$ ), Nb (462 and $41 \mathrm{ppm})$, Th (2043 and $99 \mathrm{ppm}), \mathrm{U}$ (220 and $49 \mathrm{ppm})$, and Th/U ratio (9.5 and 2.0). Elevated Hf (7284 and 7004 ppm), P (58 and 45 ppm, Table 1), Li, Sr, and Ba concentrations are less conspicuous in the light portions of zircon than those in the dark ones.

LREE versus HREE, as well as $Y$ versus total REE concentrations in zircon are indicative of a strong positive correlation (Figure $4 a, b$ ) which emphasizes the combined isomorphism of these elements. In this case, the composition points of the light and dark zircon portions do not overlap. In P versus REE, there is no correlation (Figure 4c). Additionally, there is no correlation between the $\mathrm{Eu}$ and $\mathrm{Ce}$ anomalies. (Figure 4d). Positive Ce-anomaly is more conspicuous ( $\mathrm{Ce} / \mathrm{Ce}^{*}$ ratio averages 46 and 30, respectively) in the light zircon portions than in the dark ones. The Eu-anomaly values for two types of zircon practically coincide $\left(\mathrm{Eu} / \mathrm{Eu}^{*}\right.$ ratio averages 0.79 in light zircon portions and 0.76 in dark portions, Table 1).

Th concentration generally correlates positively with $U$ concentration. This pattern is more conspicuous for dark zircon portions than for light ones (Figure 5a). If the Th/U value and $U$ concentration are compared (Figure $5 b$ ), then light zircon portions display the elevated values of both characters, but no correlation for individual light and dark zircon portions has been revealed. $\mathrm{Y}$ concentration correlates positively with $\mathrm{Nb}$ concentration (Figure 5c). This correlation is disturbed only for dark zircon portions related to the prism. Ca and Ti concentrations do not show a correlation (Figure 5d). Light zircon portions differ completely in Ti concentration from dark ones, but intersect with the latter in Ca concentration. 

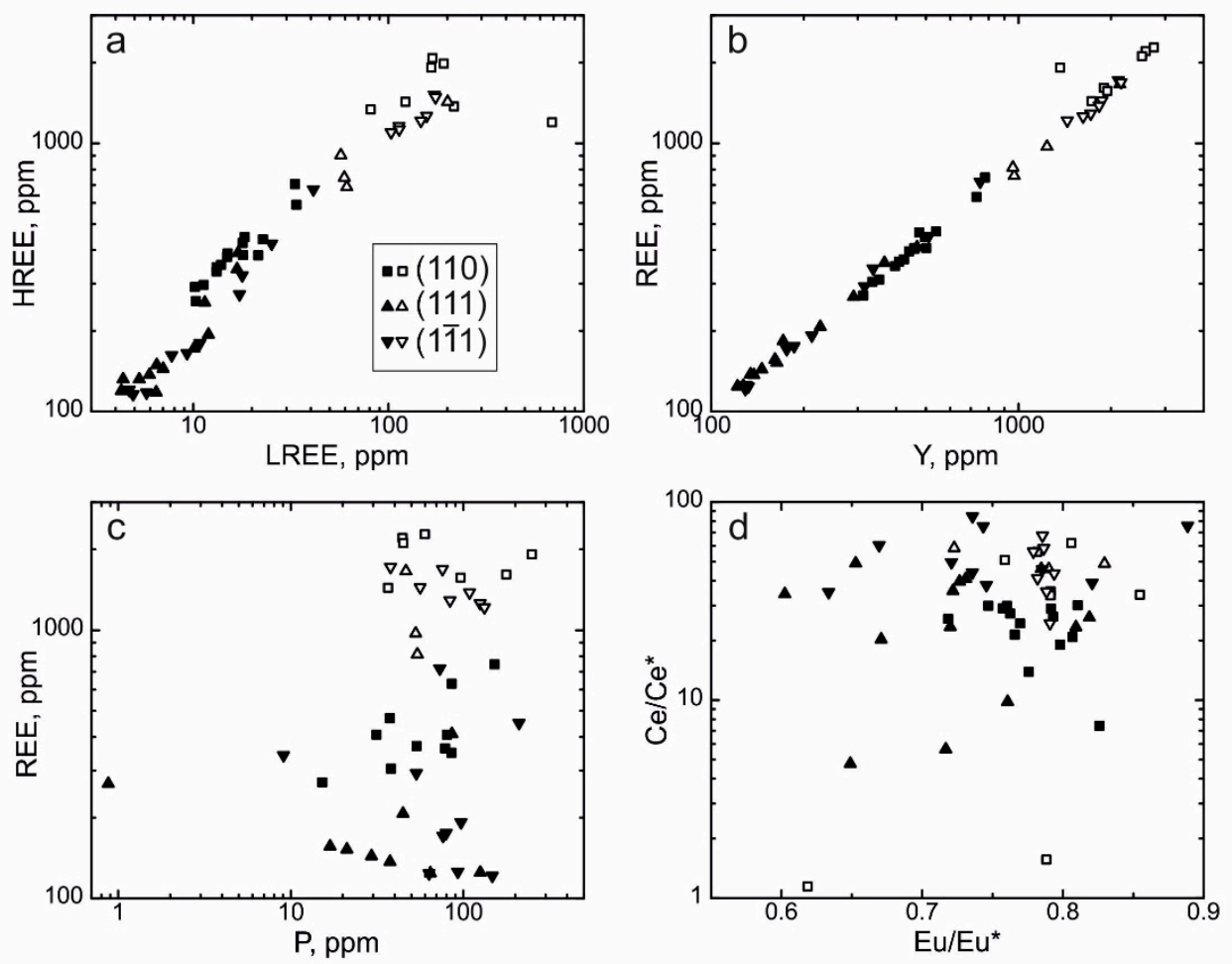

Figure 4. (a) LREE versus HREE; (b) Y versus REE; (c) P versus REE; (d) Eu/Eu* versus Ce/Ce* in zircon. Solid symbols correspond the zircon areas which are dark in BSE, open symbols represent the light in BSE zircon areas.
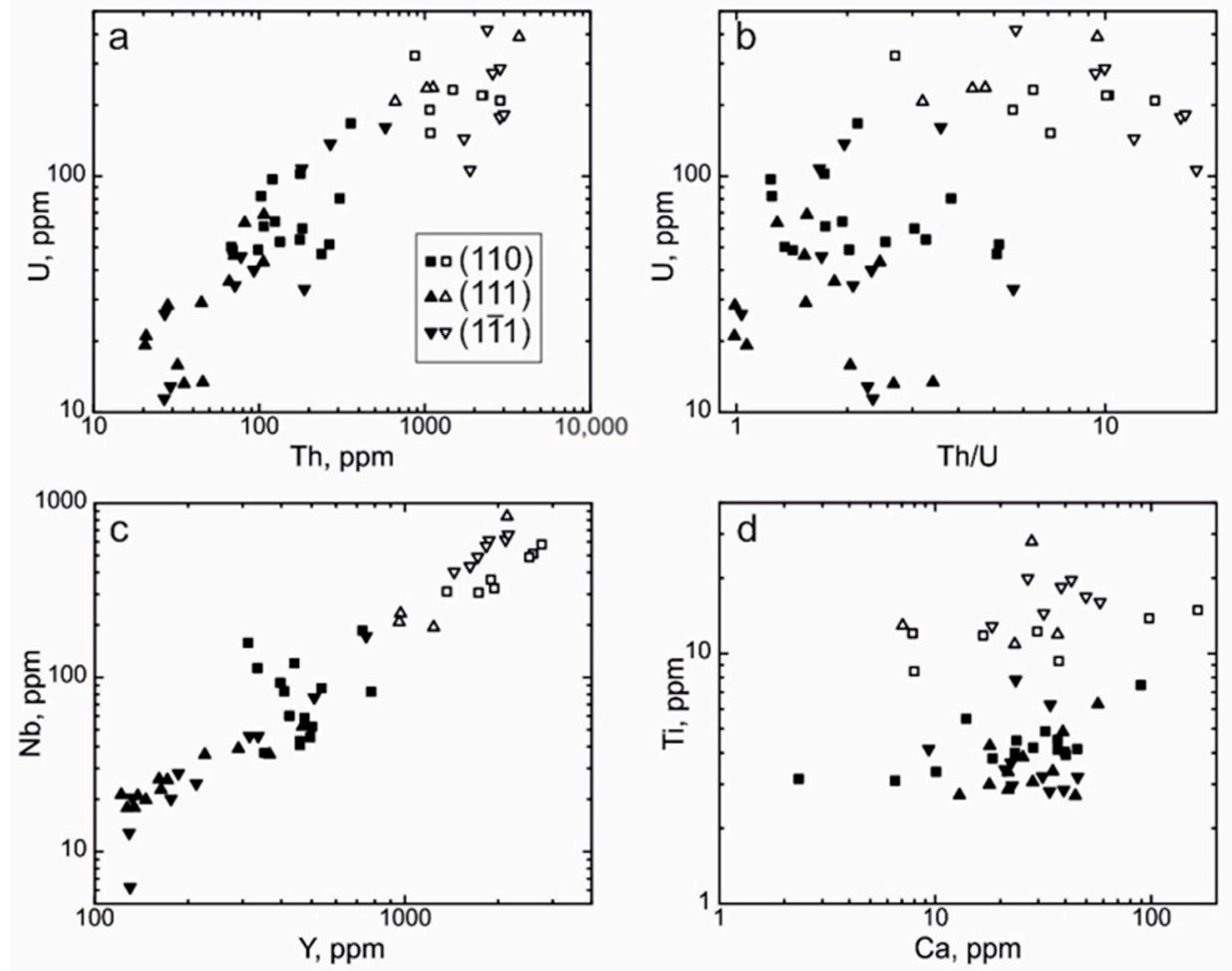

Figure 5. (a) Th versus $\mathrm{U}$; (b) Th/U versus U; (c) Y versus Nb; (d) Ca versus Ti in zircon.

4.3. REE Distribution in the Separate Growth Sectors of the Dipyramid $\{111\}$ and the Prism $\{110\}$

To compare the distribution of trace elements in different growth sectors, the average compositions of the growth sector of each form can be used. As has been shown in the 
previous section, one should consider a type of zircon (a light and or a dark bands), because differences in composition between them are more considerable than those in the growth sector of one form.

It has been shown for zircon from the bands which are light in BSE that the zircon related to the face (1111) of the dipyramid is richer in the average concentrations of most trace elements ( $\mathrm{Li}, \mathrm{P}, \mathrm{Ca}, \mathrm{Ti}, \mathrm{Y}, \mathrm{Nb}$, Th, and REE) than the zircon located within the face (111) of the same form (Table 1). Hf concentration within the various faces of the dipyramid practically coincides (7381 and $7323 \mathrm{ppm}$ ). Zircon from the face (111) of the dipyramid contains higher $U$ concentration (236 and $183 \mathrm{ppm}$, respectively) than zircon from the face (111), which, in principle, is not what could be expected, but the growth zones are hard to synchronize precisely. If the composition of the light-band zircon of the prism is compared with similar zircon (of the same zone) from the growth sector of the dipyramid, then we can see that prism contains more REE and Y, its positive Ce-anomaly is less conspicuous, the spectrum in the LREE region is more differentiated $\left(\mathrm{Sm}_{\mathrm{N}} / \mathrm{La}_{\mathrm{N}}\right.$ ratio is higher) and its Hf concentration is smaller (Table 1). Zircon from the light bands within the growth sector of the prism is in the composition variation range for zircon from the light bands of the growth sector of the dipyramid, based on the concentrations of other elements.

Comparison of the composition of zircon from dark bands of various forms is more informative, because the thickness of light bands is comparable with the size of the analytical crater. Therefore, when analyzing light bands, one should bear in mind that "poorer" zircon substance from dark bands can penetrate into the analytical field. The amount of such an impurity would be hard to estimate.

Zircon from the dark bands of the face (11̄1) of the dipyramid contains greater average quantities of $\mathrm{P}, \mathrm{Y}, \mathrm{Th}, \mathrm{U}$, and REE than zircon from the dark bands of the face (111) of the

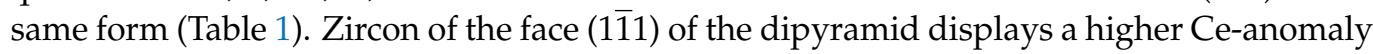
value (average value is 48$), \mathrm{Th} / \mathrm{U}$ ratio, maximum $\mathrm{REE}$ differentiation $\left(\mathrm{Lu}_{\mathrm{N}} / \mathrm{La}_{\mathrm{N}}\right.$ ratio averages 4041), and maximum $P$ concentration (average value is 78 ppm, Table 1). Zircon from the dark bands of the prism contains more Ti, $\mathrm{Y}, \mathrm{Nb}, \mathrm{Th}, \mathrm{U}$, and REE than zircon from both faces of the growth sector of the dipyramid. It displays higher LREE $\left(\mathrm{Sm}_{\mathrm{N}} / \mathrm{La}_{\mathrm{N}}\right.$ ratio averages 38) but lower HREE differentiation $\left(\mathrm{Lu}_{\mathrm{N}} / \mathrm{Gd}_{\mathrm{N}}\right.$ ratio averages 29). Zircon from the dark bands of the prism also contains low Hf concentration (Table 1).

As the zircon crystal grew, the ratio of the pyramids of forms changed considerably: the role of the prism and faces (111) of the dipyramid increased from the center of the crystal toward the edge, while face (11i1) of the dipyramid was suppressed. Therefore, the compositions of the growth sectors of forms within one grown zone, equidistant from the center of the crystal, were compared. Four growth zones, represented by wide dark bands, were selected to rule out possible compositional heterogeneity caused by the penetration of light bands into the analytical field.

The first growth zone, in which the compositions of the forms of zircon are compared, comprises six points: 6 and 14 (prism), 22 and 29 (face (111) of the dipyramid), 41 and 50 (face (1111) of the dipyramid). This growth zone is the closest to the center of the crystal, and face (111) of the dipyramid within it is not well developed yet (Figure 2). The prism zircon (points 6 and 14) contains lower Th, U, Y, and REE concentrations than the dipyramid and displays a minimum $\mathrm{Lu}_{\mathrm{N}} / \mathrm{Gd}_{\mathrm{N}}$ value. The forms differ most clearly in $\mathrm{U}$ concentration (Figure 6a). In zircon from the prism, the growth sector of the face (110) contains an average of $49 \mathrm{ppm} \mathrm{U}$, zircon from the growth sector of the face (111) of the dipyramid $66 \mathrm{ppm}$, and zircon from face (1111) of the dipyramid $122 \mathrm{ppm}$. The growth sector of the prism contains small LREE and HREE concentrations (Figure 6b). This trend is less conspicuous for Y: a similar concentration in the prism (an average of $344 \mathrm{ppm}$ ) and at the points from the growth sector of the dipyramid ( 337 and 366 ppm, Figure 6c) has been revealed. No regular patterns for $\mathrm{Nb}$ concentration are observed, and the normal correlation of these elements is disturbed (Figure 6d). Zircon of the face (1111) of the dipyramid has greater Th and $\mathrm{U}$ concentrations and a much greater Ce-anomaly value than zircon from the face (111). 

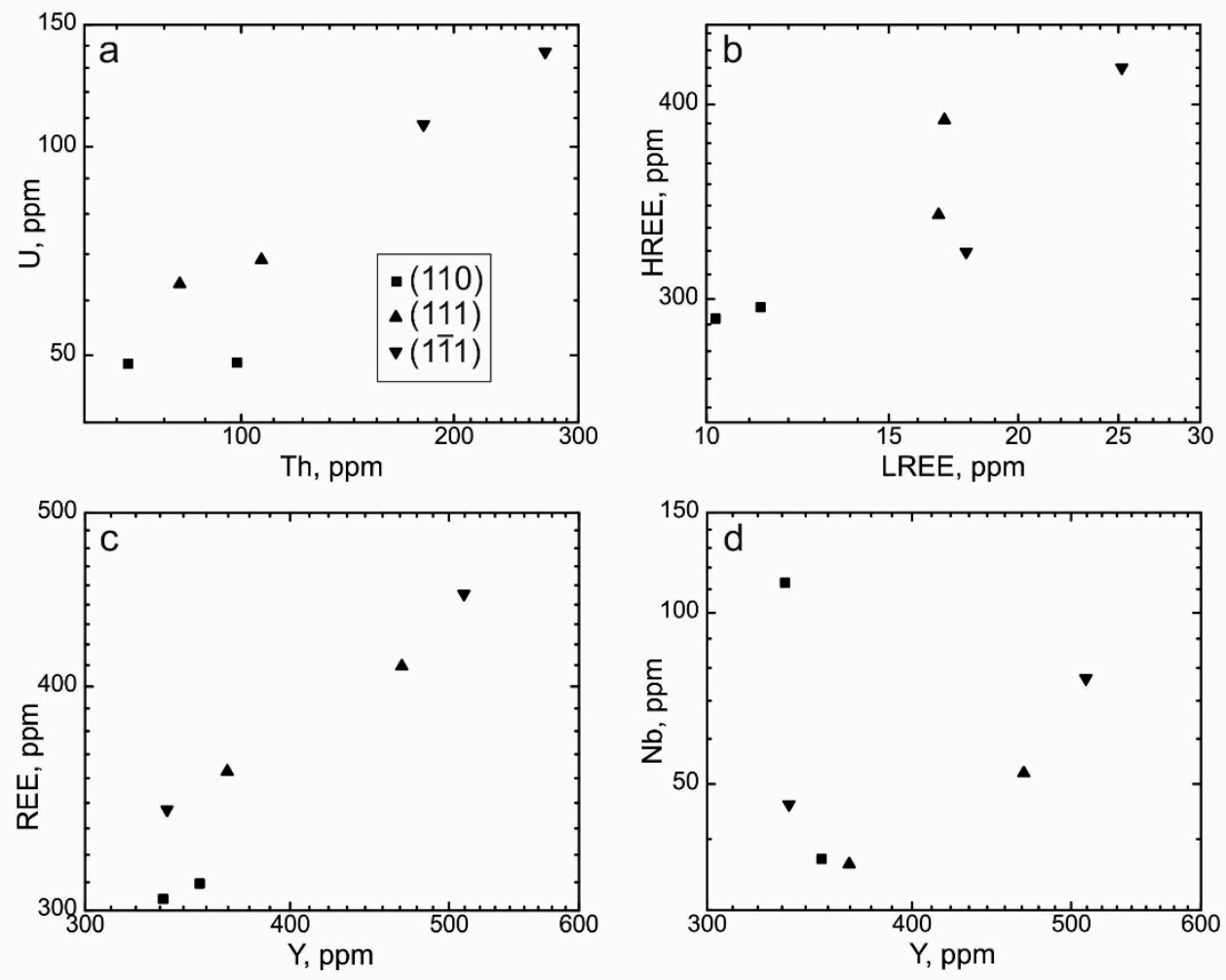

Figure 6. (a) Th versus U; (b) LREE versus HREE; (c) Y versus REE; (d) Y versus Nb in the first growth zone of zircon (points 6, 14, 22, 29, 41, и 50).

A second growth zone is represented by points 4, 12, and 20 (the face (110) of the prism), 27 and 34 (the face (111) of the dipyramid), 39 and 48 (face (111) of the dipyramid). The growth zone is located in the central portion of the crystal; the dipyramid faces within it are already equally long (Figure 2). In comparison with the first growth zone, the rare element distribution pattern changes considerably: the points within the growth sector of the prism $\{110\}$ contain elevated $\mathrm{Y}, \mathrm{Nb}, \mathrm{Th}, \mathrm{U}$, and REE concentrations. Only the $\mathrm{Lu}_{\mathrm{N}} / \mathrm{Gd}_{\mathrm{N}}$ value, which shows a more gently sloping HREE distribution pattern, remains minimal for zircon from the prism. The composition points within the prism and dipyramid do not form a common trend in the $\mathrm{Th} / \mathrm{U}$ ratio; they occur as clusters spaced wide apart (Figure 7a). The scatter of figurative points in LREE, HREE, $\mathrm{Y}$, and $\mathrm{Nb}$ concentrations is more considerable; a positive correlation is obvious, but zircon from the prism in the second growth zone contains elevated concentrations of these elements (Figure $7 \mathrm{~b}-\mathrm{d}$ ). The composition of zircon from the face (1111) of the dipyramid differs in low Th, $U$, and REE concentrations and an elevated Ce-anomaly value from that of the face (111). However, these differences are less conspicuous than those in the composition of the growth sectors of the prism and the dipyramid within the zircon crystal studied.

Points 3, 11, and 19 (110), 26 and 33 (the face (111) of the dipyramid), and 38 and 47 (face (1111) of the dipyramid) in the third growth zone, which is even closer to the edge of the zircon crystal. In this zone, the length of face (111) of the dipyramid is twice the length of the face (111) (Figure 2). Zircon from the growth sector of the prism contains elevated $\mathrm{Y}, \mathrm{Nb}, \mathrm{Th}, \mathrm{U}$, and REE concentrations (Figure 8a-d) and displays a more differentiated LREE spectrum (elevated $\mathrm{Sm}_{\mathrm{N}} / \mathrm{La}_{\mathrm{N}}$ ratio) and a gently sloping HREE spectrum (low $\mathrm{Lu}_{\mathrm{N}} / \mathrm{Gd}_{\mathrm{N}}$ ratio). The prism zircon exhibits a minimum Ce-anomaly value. It should be pointed out that in two out of three prism points ( 3 and 19, Table 1$), \mathrm{P}$ concentration is below the sensitivity limit of the ion microprobe. Zircon of the face (1111) of the dipyramid contains a maximum $P$ concentration. 

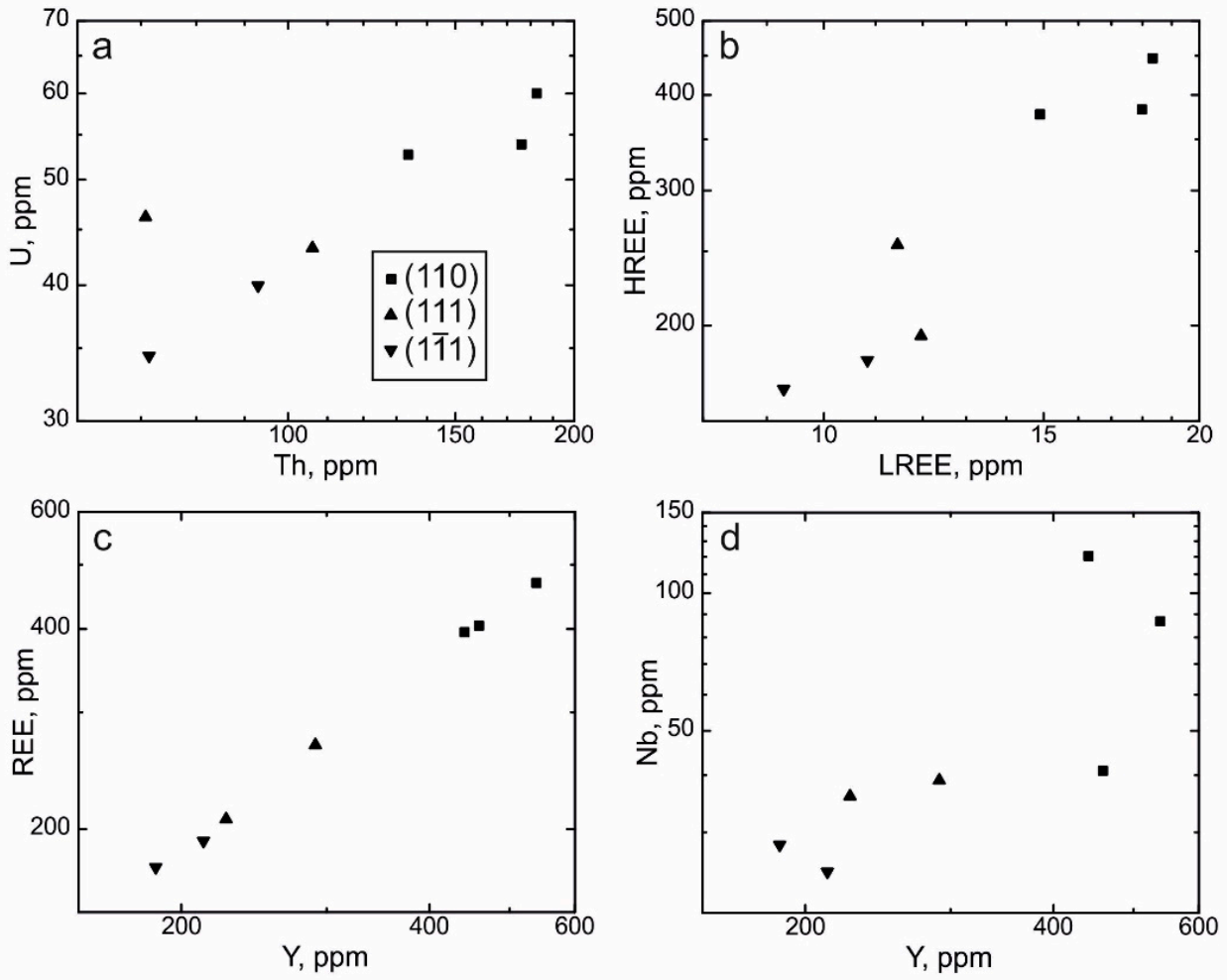

Figure 7. (a) Th versus U; (b) LREE versus HREE; (c) Y versus REE; (d) Y versus Nb in the second growth zone of zircon (points 4, 12, 20, 27, 34, 39, и 48).
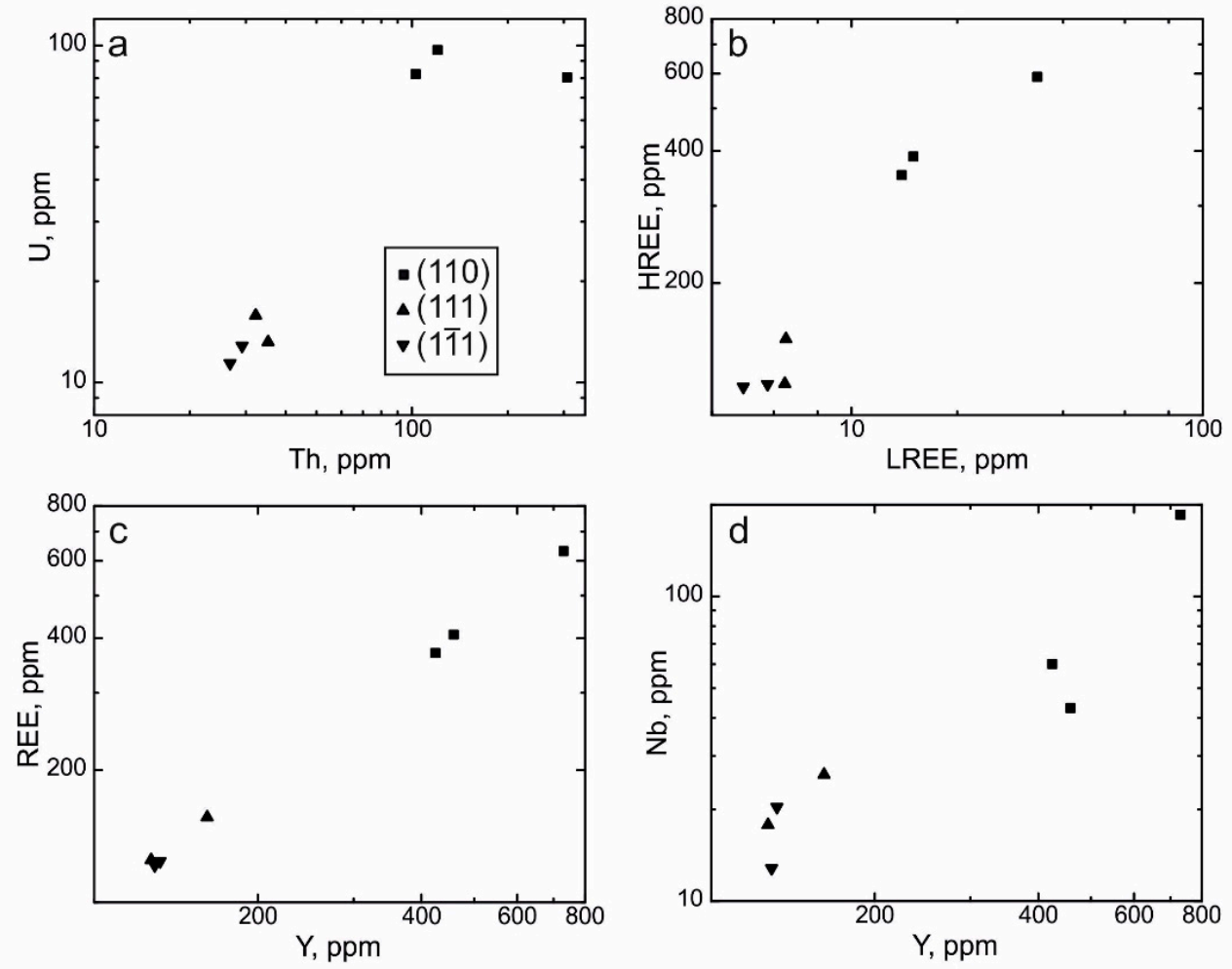

Figure 8. (a) Th versus U; (b) LREE versus HREE; (c) Y versus REE; (d) Y versus Nb in the third growth zone of zircon (points 3, 11, 19, 26, 33, 38, и47).

The fourth growth zone, selected for comparison of the compositions of the forms, is located on the zircon margin. Three points $(1,9$, and 17$)$ are in the prism and another 
three $(25,31$ and 36$)$ are in the face (111) of the dipyramid (Figure 2). As the face (1111) of the dipyramid is practically reduced, there is only one point (45) in it. As in the previous growth zone, zircon from the growth sector of the prism differs from zircon from the dipyramid in elevated $\mathrm{Y}, \mathrm{Nb}, \mathrm{Th}, \mathrm{U}$, and REE concentrations, an elevated $\mathrm{Sm}_{\mathrm{N}} / \mathrm{La}_{\mathrm{N}}$ ratio and a low $\mathrm{Lu}_{\mathrm{N}} / \mathrm{Gd}_{\mathrm{N}}$ ratio (Figure $9 \mathrm{a}-\mathrm{d}$ ). Two out of three points within the prism $\mathrm{P}$ concentration is minimal (at point 17 it is below detection limits and at point 1 it is $15 \mathrm{ppm}$ ). An interesting feature of the marginal growth zone is inversion in the composition of the faces (111) and (1111) of the dipyramid. In contrast to two previous growth zones, zircon from the growth sector of the face (1111) contains more $\mathrm{Y}, \mathrm{Th}, \mathrm{U}, \mathrm{REE}$, and $\mathrm{P}$ than zircon from the growth sector of the face (111) and displays an elevated Ce-anomaly value.
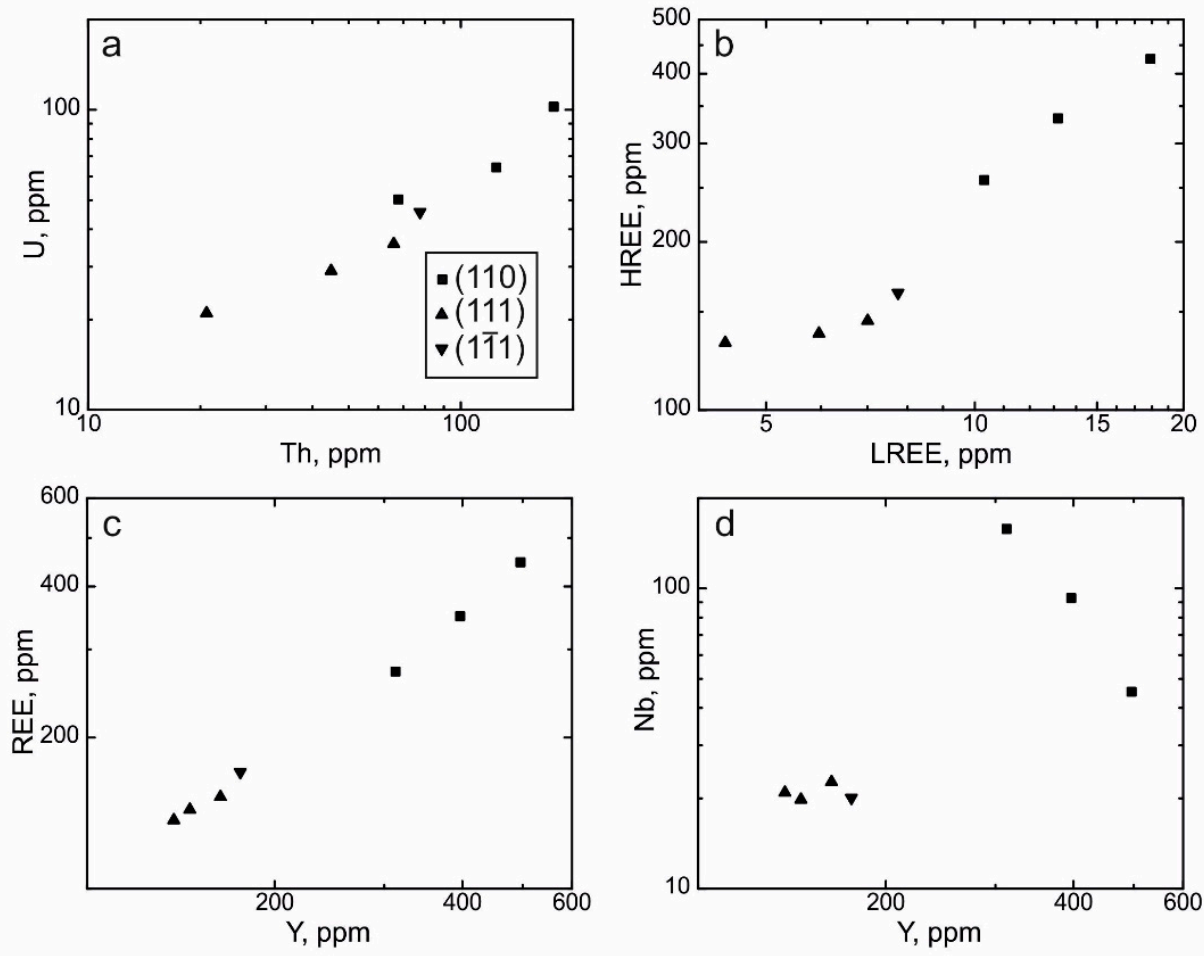

Figure 9. (a) Th versus U; (b) LREE versus HREE; (c) Y versus REE; (d) Y versus Nb in the fourth growth zone of zircon (points 1, 9, 17, 25, 31, 36, и 45).

\subsection{Trace Elements Distribution in Growth Zones}

The growth zoning pattern of zircon can be traced along several profiles oriented perpendicular to growth zoning. The local character of the ion microprobe is the reason why the zoning, composed of intricately alternating light and dark zircon portions, cannot be reconstructed in detail. However, an attempt to describe a general growth zoning pattern, especially in the dark wide portions of zircon, can be made.

In the growth sector of the face (110) of the prism, such a profile consists of eight points. The initial points of the profile (16 and 15) are in the dark bands of zircon, while the other six (14-9) are in the light portions. Figure 10 shows the distribution of the elements in the zircon in the growth sector of the prism. As has been noted above, the initial points within the light bands display a considerable enrichment in HREE, LREE, $\mathrm{Y}, \mathrm{Nb}$, Th, and $\mathrm{U}$. Toward the external portion of the profile within the dark bands Y, HREE, LREE, $\mathrm{U}$, and $\mathrm{Nb}$ concentrations decrease in a stepwise manner and then vary slightly over the entire profile. $\mathrm{Nb}$ concentration tends to rise steadily from 37 to $93 \mathrm{ppm}$ toward the crystal margin after a drop from a concentration of about $500 \mathrm{ppm}$. Th concentration varies irregularly from 100 to $265 \mathrm{ppm}$ after a drop from over $2200 \mathrm{ppm}$. Ti concentration declines gently from the center of the crystal to its margin from 12 to $4 \mathrm{ppm}$ and then remains unchanged toward the crystal margin. There is a drop in concentration down to about $3 \mathrm{ppm}$ at point 14 , the 
first in a sequence of dark portions of zircon that follow the light bands. At the same point, a minimum Ca concentration ( $2 \mathrm{ppm})$ correlates with a drop in Ti concentration. On the contrary, Ca concentration at the beginning of the profile is as low as 8 ppm in the light bands (points 16 and 15). Ca concentration rises to $45-40$ ppm toward the crystal margin (points 9 and 10). At points 14 and 13, P concentration drops (below detection limits from about $50 \mathrm{ppm}$ ), as does Sr concentration. Sr concentration, in principle, persists along the profile at about $1 \mathrm{ppm}$ but decreases to $0.3 \mathrm{ppm}$ at points 14 and 13 . This correlation in the behavior of $\mathrm{P}, \mathrm{Ca}$, and $\mathrm{Sr}$ within the profile in zircon suggests apatite crystallization simultaneous with the crystallization of the corresponding growth zone of zircon where points 14 and 13 are located. Another decline in P concentration (down to $38 \mathrm{ppm}$ ) at point 11 is less considerable. Ca concentration decreases there to $28 \mathrm{ppm}$. Point 11 is located in the dark band of zircon intergrown with apatite crystals identified by typical hexagonal cross-sections (the right portion of Figure 2). Therefore, it is safe to assume that combined crystallization with apatite in this portion of growth zoning affects the trace element content of zircon.

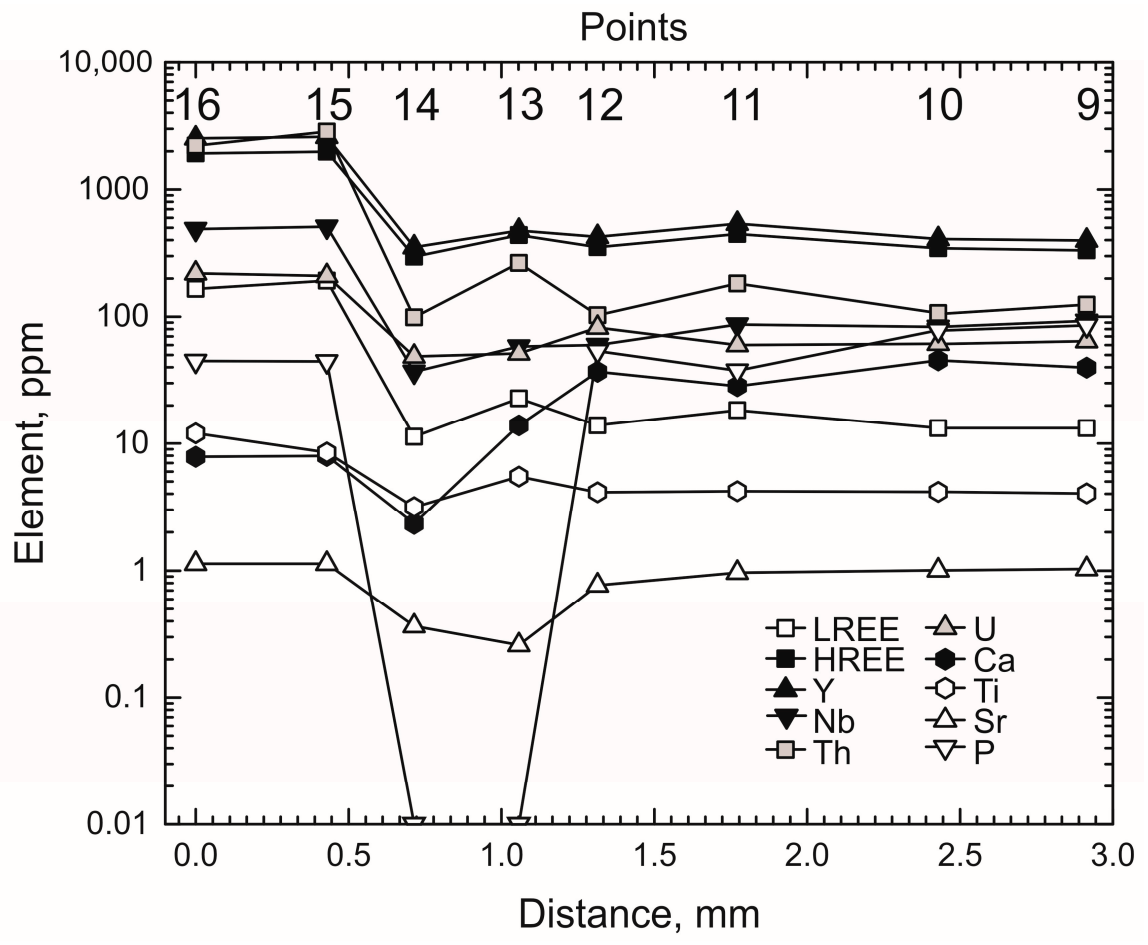

Figure 10. Trace elements zoning of zircon in the growth sector of the prism.

Within the face (111) of the dipyramid, the profile discussed consists of seven points (29-24). All the points, except for the fifth from the center of the crystal (point 25-2 in the light band), are in dark zircon (Figure 2). At point 25-2 REE, Y, Nb, Th, and U concentrations increase considerably and also rise gradually at point 26 (Figure 11). Ti concentration increases slightly to $11 \mathrm{ppm}$, as compared to $4 \mathrm{ppm}$ at neighboring points. If the growth zoning pattern is discussed without considering the effect of the presence of a light band rich in trace elements, then $\mathrm{REE}, \mathrm{Y}, \mathrm{Nb}$, and Th seem to display a decline in concentration from the center of the crystal toward the margin within face (111) of the dipyramid. The behavior of $\mathrm{U}, \mathrm{Ca}, \mathrm{Ti}$, and $\mathrm{Sr}$ displays no well-defined regular pattern. $\mathrm{P}$ concentration tends to increase from the center of the crystal toward the margin. Three points, at which P concentration is extremely low (below detection limits at points 29 and 28 and about 1 ppm at point 26), coincide in position with the points in the profile of the prism (points 14, 13, and 11) which are also depleted in P. However, no decline in Ca and Sr concentrations in the profile within the face (111) of the dipyramid, complementary to drops in $\mathrm{P}$, has been revealed. 


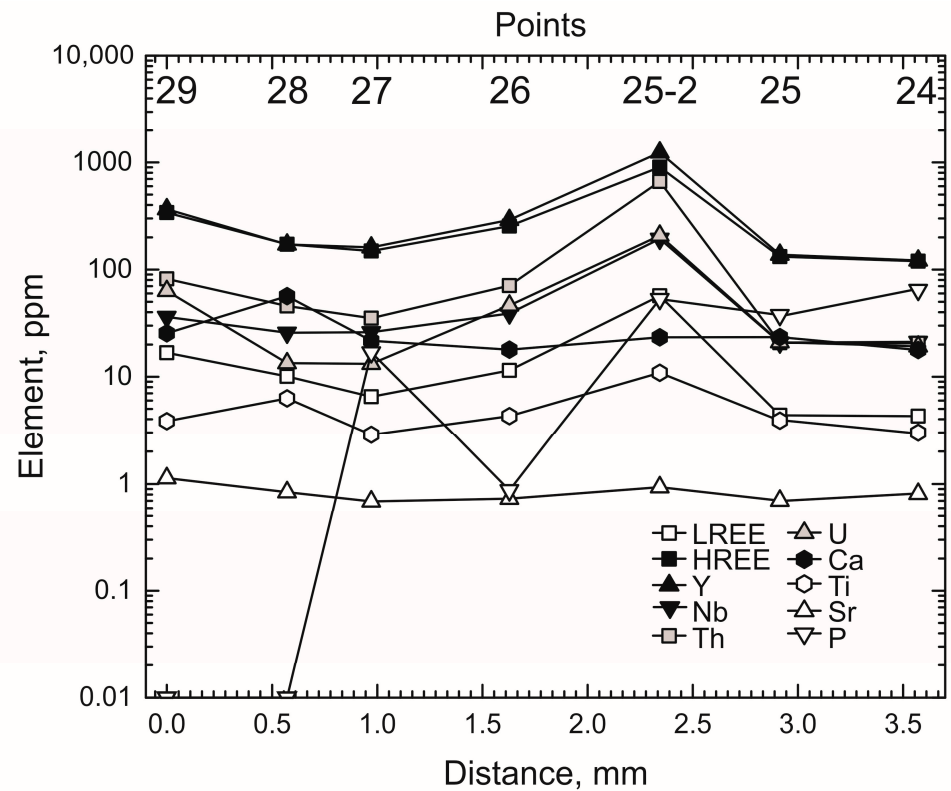

Figure 11. Trace elements zoning of zircon in the growth sector of the face (111) of the dipyramid.

The profile within the growth zone of the face $(1 \overline{1} 1)$ of the dipyramid consists of ten points (53-44) four of which are in the light bands of zircon (points 52, 51, 49, and 46, Figure 2). REE, Y, Nb, Th, and U concentrations in the light bands increase markedly, as they do in the profile for the face (111) of the pyramid (Figure 12). Ti concentration in the light bands increases in a more contrasting manner (up to $20 \mathrm{ppm}$ as compared to 3-4 ppm at the points near the light bands) than in the previous profile. The same patterns (REE, $\mathrm{Y}, \mathrm{Nb}$, and Th concentrations decrease from the center of the crystal toward the margin) persist for the points within the dark bands and for the profile within the face (111). U, Ca, and Ti distribution in the dark zircon portions of the profile is generally uniform. $\mathrm{P}$ concentration increases toward the crystal margin, and there are no drops in $\mathrm{P}$ concentration below detection limits of the ion microprobe over the entire profile observed for the profiles within the growth zones of other faces.

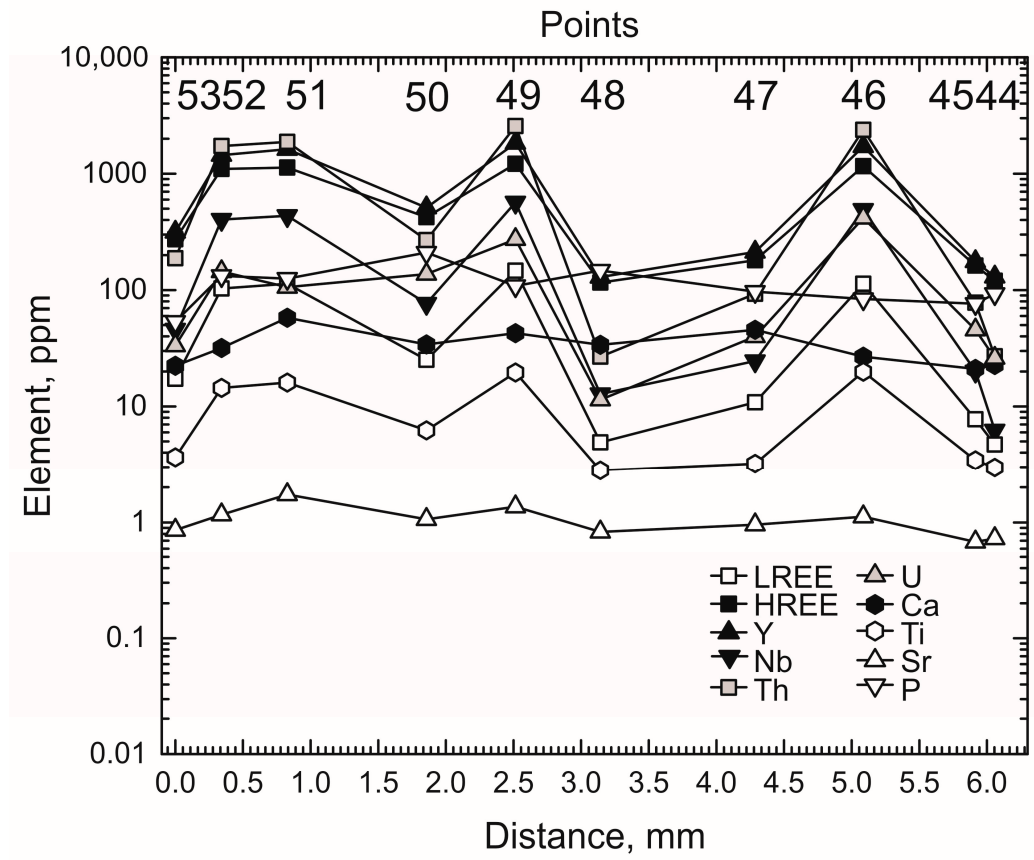

Figure 12. Trace elements zoning of zircon in the growth sector of the face (1111) of the dipyramid. 


\section{Discussion}

Growth zoning is the main factor responsible for the composition of zircon from Ilmen Mountains feldspathic pegmatite. This zoning of zircon is formed of alternating wide and BSE-dark bands with numerous thin and BSE-light bands (Figure 2). As has been shown above (Table 1, Table S1), zircon from the light bands is considerably (even by an order of magnitude) enriched in $\mathrm{Th}, \mathrm{U}, \mathrm{REE}, \mathrm{Y}, \mathrm{Nb}$, and $\mathrm{Ti}$ (increase in the level of $\mathrm{Li}$ and $\mathrm{P}$ content is less significant) in comparison with zircon from the dark bands. BSE-light zircon displays elevated Th/U ( 9.5) and Ce-anomaly (Ce/Ce* an average of 46) values. Zircon from BSE-dark bands differs only in elevated HREE differentiation $\left(\mathrm{Lu}_{\mathrm{N}} / \mathrm{Gd}_{\mathrm{N}}\right.$ ratio, Table 1). The reason for this zoning is hard to explain. On the one hand, it differs from a typical magmatic oscillatory zoning described in detail in [50]. On the one hand, oscillatory zoning, associated with the crystallization of zircon from melt, is neither characteristic of pegmatitic zircon nor common. On the other hand, the zoning of the zircon discussed differs completely from the zoning revealed in zircon of hydrothermal-metasomatic type [53]. The latter is due to the re-equilibration of zircon composition upon the disequilibrium of fluid and large-scale dissolution-reprecipitation of zircon. Zircon with a metasomatic zoning typically displays an irregular and spotted structure and rugged zone boundaries to which abundant accessory mineral microinclusions are commonly confined.

A zoning, morphologically similar to the one described above, was revealed in zircon from Elba igneous granitoid complex Elba [54]. In zircon, narrow BSE-light bands contain elevated U, Th, Y, and HREE concentrations and low Hf concentration. Conversely, much darker bands are depleted in the above elements but enriched in Hf. The authors propose several reasons for this zoning. The main reason is the compositional alternation of the melt from which zircon is crystallized, from equilibrium with monazite composition (depleted in LREE and, correspondingly, enriched in HREE and $Y$ and the elements which correlate with them) to non-fractionated for REE distribution. In this case, light bands in zircon result from non-equilibrium resorption [54]. In this case, the presence or absence of trace element enriched BSE-light bands in zircon, also depends most probably on a regime in which accessory minerals (apatite, monazite, etc.) are crystallized together with zircon. Our assumption is supported by the study of growth zoning in individual forms. On the diagram of growth zoning in the prism (Figure 10), a drop in the concentrations of some elements is consistent with crystallization of the dark bands of zircon which is in contact with apatite and monazite.

Sector zoning, understood as joint crystallization of the prism $\{110\}$ and dipyramid $\{111\})$, is well-defined in the zircon studied. Compositions were compared first for dark zircon to rule out the non-uniform penetration of light bands, much richer in trace elements, into the analytical field. Zircon from the prism $\{110\}$ generally contains more Th, $\mathrm{U}$, REE, $\mathrm{Y}$, and $\mathrm{Nb}$, displays a more gently sloping HREE distribution spectrum and a steeper LREE spectrum, in contrast to zircon from the dipyramid $\{111\}$ (Table 1). Concentrations of other elements in zircon from the various growth sectors of the forms are roughly identical.

The above relationship is valid for three growth zones which are closer to the crystal margin (Figures 7-9). There, the growth sector of the prism dominates over the faces of the growth sector of the dipyramid. The length of the face (111) of the dipyramid in them is about two-three times smaller than the face (110) of the prism, and the face (1111) of the dipyramid is suppressed (Figure 2).

In the growth zone of zircon, which is the closest to the center of the crystal, the trace element distribution shows an inverse pattern: zircon from the prism is depleted in Th, $\mathrm{U}, \mathrm{REE}$, and Y (Figure 6). This inversion of properties is due to the rapid growth of the face (111) of the dipyramid in comparison with that of the prism upon crystal formation. This assumption is also supported also by the abundance and thickness of the light bands in the growth zone of the face (1111) of the dipyramid, while in the prism, they are poorly evolved (Figure 2). In this growth zone, zircon from the face (111) of the dipyramid contains more Th and $U$ than zircon from the face (111) of the same form. As the face (111) of the dipyramid grows due to the shortening of the face (111), their composition does not differ 
considerably. For zircon from the dark bands of the face (11̄1) of the dipyramid, we have estimated the maximum value of positive Ce-anomaly $\left(\mathrm{Ce} / \mathrm{Ce}^{*}\right)$ and the degree of the total differentiation of the REE spectrum $\left(\mathrm{Lu}_{\mathrm{N}} / \mathrm{La}_{\mathrm{N}}\right.$ ratio) in comparison with zircon from the face (111) of the dipyramid and that (110) of the prism (Table 1).

Attempts to compare zircon composition with a sectorial zoning were made earlier. For example, it was shown for Lewisian gneiss that zircon from a prism $\{100\}$ is enriched in $\mathrm{Y}$ and depleted in Hf in comparison with zircon from another prism \{110\} [55]. However, as the zircon crystal was cut perpendicular to the elongation axis L4 [001], the authors succeeded in comparing only the compositions of the growth sectors of tetragonal prism. Furthermore, 35 analytical points by the microprobe were all placed on the crystal margin. Therefore, the probable growth zoning of zircon was not described.

It has been shown for zonal zircon from the Bishop Tuff [56] that a difference in concentrations of some trace elements in a prism and a dipyramid in the same growth zone can be two-fold. Th, Nb, U, LREE, and Ti concentrations in the dipyramid are greater than those in the prism. On the contrary, $\mathrm{P}$ concentration in the prism is greater than that in the dipyramid.

Zircon from Ilmen Mountains feldspathic pegmatite exhibits no significant positive correlation in $\mathrm{P}$ and REE concentrations (Figure $4 \mathrm{~b}$ ), as suggested by the scheme of heterovalent isomorphism of xenotime type $(\mathrm{Zr}+\mathrm{Si})^{4+}=(\mathrm{REE}+\mathrm{Y})^{3+}+\mathrm{P}^{5+}$ in zircon [57]. The absence of P-REE correlation has been revealed earlier for zircon from I-granites [58]. As total REE concentration increases to 1000-2000 ppm, P concentration of 100-200 ppm remains unchanged. Such a deviation has been revealed earlier for high yttrium zircon which contains large quantities of incompatible elements, including water [59]. In this case, the scheme of isomorphism $\mathrm{H}^{+}+(\mathrm{REE}+\mathrm{Y})^{3+}=\mathrm{Zr}^{4+}$ is at work [27]. However, the presence of water in zircon leads to the disturbance of its crystalline structure. As a result, $\mathrm{Ca}, \mathrm{Sr}$, and $\mathrm{Ba}$ concentrations increase. In our case, $\mathrm{Ca}, \mathrm{Sr}$, and $\mathrm{Ba}$ concentrations are rather low and do not correlate with zircon zoning. Therefore, further study is needed to interpret the absence of P-REE correlation (Figure 4c).

In the zircon studied, special attention should be given to Ti distribution used in calculation of zircon crystallization temperature [48]. The dark portions of zircon contain about $4 \mathrm{ppm} \mathrm{Ti}$, while its light portions carry up to $13 \mathrm{ppm}$ and in the growth zones of the face (1111) of the dipyramid up to $17 \mathrm{ppm}$ (Table 1). Zircon crystallization temperature, calculated using a Ti-thermometer, varies accordingly from 650 to $800{ }^{\circ} \mathrm{C}$. Light bands, containing elevated concentrations of $\mathrm{Ti}$ and other trace elements, alternate in a uniform manner with Ti-depleted dark bands (Figure 2). Obviously, zircon could have hardly crystallized at continuously varying temperatures of about $150{ }^{\circ} \mathrm{C}$.

The NanoSIMS study of the distribution of Ti and other trace elements in zircon at a submicron level showed that Ti concentration varies markedly even within short distances and depends on a kinetic factor, rather than a temperature-dependent distribution between melt and zircon $[60,61]$. The above examples suggest some limits in the use of a Tithermometer. Considering a possible lack of equilibrium in zircon composition in light bands, an average value of $\sim 650^{\circ} \mathrm{C}$ for the dark portions of zircon (Table 1), consistent with geological data, could be taken for crystallization temperature. The average temperature value for the prism $\{110\}$ differs by only $15^{\circ} \mathrm{C}$ from that for the dipyramid $\{111\}$. This difference is most probably close to the analytical error in estimation of Ti concentration. Therefore, the scheme, widely used for calculation of zircon crystallization temperature of $500-900{ }^{\circ} \mathrm{C}$ from the dominance of one or another from $[25,26]$, should be supported by independent evidence.

\section{Conclusions}

The detailed ion microprobe study of trace and rare earth element distribution in the growth sectors and zones in a coarse zircon crystal from Ilmen Mountains feldspathic pegmatite has led the authors to conclude that: 
1. The zircon studied displays zoning formed of alternating wide BSE-dark and thin BSElight bands. The last ones contain elevated $\mathrm{Th}, \mathrm{U}, \mathrm{REE}, \mathrm{Y}, \mathrm{Nb}$, and Ti concentrations, $\mathrm{Th} / \mathrm{U}$ ratio and $\mathrm{Ce} / \mathrm{Ce}^{*}$. The zoning is most probably due to combined crystallization of minerals that concentrate trace elements, e.g., apatite and monazite, and the lack of equilibrium between zircon and fluid (melt).

2. Zircon from the growth sector of the prism $\{110\}$ generally contains more $T h, U$, $\mathrm{REE}, \mathrm{Y}$, and $\mathrm{Nb}$ and exhibits a more gently sloping HREE distribution pattern and a steeper LREE distribution pattern, in contrast to zircon from the growth sector of the dipyramid $\{111\}$. Concentrations of other elements in zircon from these two forms are roughly identical.

3. Such a sector zoning pattern was formed at a late stage in crystal growth, when the prism $\{110\}$ began to prevail over the dipyramid $\{111\}$. At an early crystallization stage, the prism and the dipyramid grew at comparable speed, but zircon from the prism contained less Th, U, REE, and Y.

4. Considerable variations in $\mathrm{Th}, \mathrm{U}$, and Ti concentrations and $\mathrm{Th} / \mathrm{U}$ ratio, the characteristics widely used for assessment of the conditions of formation of zircon and capable of affecting age dating, were revealed within one zircon crystal. Therefore, the possible growth and sector zoning of zircon should be taken into account in $\mathrm{U}-\mathrm{Pb}$ dating studies and in the designing of geothermometers, geobarometers, and other indicators.

Supplementary Materials: The following are available online at https://www.mdpi.com/2076-326 3/11/1/7/s1, Table S1: Distribution of trace and rare earth elements (ppm) of the zircon from Ilmen Mountains feldspathic pegmatite.

Author Contributions: Investigation, E.V.L., S.G.S. and V.A.P.; Supervision, S.G.S.; Writing—original draft, E.V.L. and S.G.S.; Writing — review \& editing, V.A.P. All authors have read and agreed to the published version of the manuscript.

Funding: The study was conducted under state contracts of Institute of Precambrian Geology and Geochronology of Russian Academy of Sciences and partly carried out within the state contracts of South Ural Federal Scientific Center for Mineralogy and Geoecology of the Ural Branch of the Russian Academy of Sciences.

Data Availability Statement: Data available in a publicly accessible repository.

Acknowledgments: We thank O.L. Galankina (IPGG, RAS) for assistance with the BSE images of zircons, S.G. Simakin and E.V. Potapov (YB IPT RAS) for assistance with measuring of zircon trace element compositions. Three anonymous reviewers pro-vided valuable comments that improved the quality of the report.

Conflicts of Interest: The authors declare no conflict of interest.

\section{References}

1. Watson, E.B.; Liang, Y. A simple model for sector zoning in slowly grown crystals: Implications for growth rate and lattice diffusion, with emphasis on accessory minerals in crystal rocks. Am. Mineral. 1995, 80, 1179-1187. [CrossRef]

2. Watson, E.B. Surface enrichment and trace-element uptake during crystal growth. Geochim. Cosmochim. Acta 1996, 60, 5013-5020. [CrossRef]

3. Dowty, E. Crystal structure and crystal growth: II. Sector zoning in minerals. Am. Mineral. 1976, 61, 460-469.

4. Reeder, R.J.; Rakovan, J. Surface structural controls on trace element incorporation during crystal growth. In Growth, Dissolution and Pattern-Formation in Geosystems; Jamtveit, B., Meakin, P., Eds.; Kluwer Academic Publishers: Norwell, MA, USA, 1999; pp. $143-162$.

5. Hughes, J.M.; Cameron, M.; Mariano, A.N. Rare-earth-element ordering and structural variations in natural rare-earth-bearing apatites. Am. Mineral. 1991, 76, 1165-1173.

6. Rakovan, J.; Reeder, R.I. Differential incorporation of trace elements and dissymmetrization in apatite: The role of surface structure during growth. Am. Mineral. 1994, 79, 892-903.

7. Rakovan, J.; Reeder, R.J. Intracrystalline rare earth element distributions in apatite: Surface structural influences on zoning during growth. Geochim. Cosmochim. Acta 1996, 60, 4435-4445. [CrossRef] 
8. Rakovan, J.; McDaniel, D.K.; Reeder, R.J. Use of surface-controlled REE sectoral zoning in apatite from Llallagua, Bolivia, to determine a single-crystal Sm-Nd age. Earth Planet. Sci. Lett. 1997, 146, 329-336. [CrossRef]

9. Rakovan, J.; Luo, Y.; Borkiewicz, O. Synchrotron microanalytical methods in the study of trace and minor elements in apatite. Mineralogia 2008, 39, 31-40. [CrossRef]

10. Paterson, B.A.; Stephens, W.E.; Herd, D.A. Zoning in granitoid accessory minerals as revealed by backscattered electron imagery. Mineral. Mag. 1989, 53, 55-61. [CrossRef]

11. Bosze, S.; Rakovan, J. Surface structure controlled sectoral zoning of the rare-earth elements in fluorite from Long Lake, N.Y. and Bingham, N.M. Geochim. Cosmochim. Acta 2002, 66, 997-1009. [CrossRef]

12. Repina, S.A. Fractionation of REE in the xenotime and florencite paragenetic association from Au-REE mineral occurrences of the near-Polar Urals. Geochem. Int. 2011, 49, 868-887. [CrossRef]

13. Repina, S.A.; Khiller, V.V.; Makagonov, E.P. Microheterogeneity of crystal growth zones as a result of REE fractionation. Geochem. Int. 2014, 52, 1057-1071. [CrossRef]

14. Vavra, G. On the kinematics of zircon growth and its petrogenetic significance: A cathodoluminescence study. Contrib. Mineral. Petrol. 1990, 106, 90-99. [CrossRef]

15. Vavra, G.; Gebauer, D.; Schmid, R.; Compston, W. Multiple zircon growth and recrystallization during polyphase Late Carboniferous to Triassic metamorphism in granulites of the Ivrea Zone (Southern Alps): An ion microprobe (SHRIMP) study. Contrib. Mineral. Petrol. 1996, 122, 337-358. [CrossRef]

16. Sturm, R. Morphology and growth trends of accessory zircons from various granitoids of the South-western Bohemian Massif (Moldanubicum, Austria). Geochemistry 2010, 70, 185-196. [CrossRef]

17. Sturm, R. Internal morphology and crystal growth of accessory zircon from igneous rocks. In Zircon and Olivine; van Dijk, G., van den Berg, V., Eds.; Nova Science Publishers: Hauppauge, NY, USA, 2012; pp. 37-65.

18. Paquette, I.; Reeder, R.I. Relationship between surface structure, growth mechanism, and trace element incorporation in calcite. Geochim. Cosmochim. Acta 1995, 59, 735-749. [CrossRef]

19. Kukui, A.L.; Skublov, S.G. Geochemistry of rare earth elements in Iceland spars from deposits in the Siberian Craton. Dokl. Earth Sci. 2008, 418, 109-113. [CrossRef]

20. Schwandt, C.S.; McKay, G.A. Minor- and trace-element sector zoning in synthetic enstatite. Am. Mineral. 2006, 91, 1607-1615. [CrossRef]

21. Lofgren, G.E.; Huss, G.R.; Wasserburg, G.J. An experimental study of trace-element partitioning between Ti-Al-clinopyroxene and melt: Equilibrium and kinetic effects including sector zoning. Am. Mineral. 2006, 91, 1596-1606. [CrossRef]

22. Stowell, H.; Zuluaga, C.S.; Boyle, A.; Bulman, G. Garnet sector and oscillatory zoning linked with changes in crystal morphology during rapid growth, North Cascades, Washington. Am. Mineral. 2011, 96, 1354-1362. [CrossRef]

23. Trail, D. Heterogeneous distribution of trace elements in zircon. In Proceedings of the Goldschmidt 2014, Sacramento, CA, USA, 8-13 June 2014; p. 2510.

24. Benisek, A.; Finge, F. Factors controlling the development of prism faces in granite zircons: A microprobe study. Contrib. Mineral. Petrol. 1993, 114, 441-451. [CrossRef]

25. Pupin, J.P. Zircon and granite petrology. Contrib. Mineral. Petrol. 1980, 73, 207-220. [CrossRef]

26. Pupin, J.P. Granites as indicators in paleogeodynamics. Rend. Soc. Ital. Mineral. Petrol. 1988, 43, $237-262$.

27. De Hoog, J.C.M.; Lissenberg, C.J.; Brooker, R.A.; Hinton, R.; Trail, D.; Hellebrand, E. Hydrogen incorporation and charge balance in natural zircon. Geochim. Cosmochim. Acta 2014, 141, 472-486. [CrossRef]

28. Burnham, A.D. Key concepts in interpreting the concentrations of the rare earth elements in zircon. Chem. Geol. 2020, 551, 119765. [CrossRef]

29. Kapustin, Y.L. Distribution of trace elements in accessory zircon of various generations from pegmatites. Geochemistry 1985, 4 , 514-528. (In Russian)

30. Popova, V.I. Identification of elemental and isotopic zoning and sectoriality of large crystals of minerals using neutron radiography. Mineralogy 2015, 1, 25-33. (In Russian)

31. Nedosekova, I.L.; Vladykin, N.V.; Pribavkin, S.V.; Bayanova, T.B. The Il'mensky-Vishnevogorsky miaskite-carbonatite complex, the Urals, Russia: Origin, ore resource potential, and sources. Geol. Ore Depos. 2009, 51, 139-162. [CrossRef]

32. Popov, V.A.; Popova, V.I. Mineralogy of pegmatites of the Ilmen mountains. In Mineralogical Almanac; ECOST Association: Moscow, Russia, 2006; Volume 9, p. 152. (In Russian)

33. Levin, V.Y.; Ronenson, B.M.; Samkov, V.S.; Levina, I.A.; Sergeev, N.S.; Kiselev, A.P. Alkaline-Carbonatite Complexes of the Urals; Uralgeolkom: Ekaterinburg, Russia, 1997; p. 274. (In Russian)

34. Popova, V.I.; Chesnokov, B.V. Anatomy of zircon crystals from alkaline pegmatites of the Vishnevye mountains. In Ontogeny of Pegmatites of the Urals; USC USSR Academy of Sciences: Sverdlovsk, Russia, 1980; pp. 91-101. (In Russian)

35. Popova, V.I. Zircons of the Ilmen mountains: Touches of history and the new data. In Scientific Relations between Germany and Russia for the Study of Ilmen Mountains; Institute of Mineralogy Uralian Branch of RAS: Miass, Russia, 2002; pp. 46-54. (In Russian)

36. Krasnobaev, A.A.; Valizer, P.M.; Anfilogov, V.N.; Nemova, A.B.; Busharina, S.V. Zirconology of pegmatites of the Ilmeny Mountains. Dokl. Earth Sci. 2014, 457, 960-964. [CrossRef]

37. Nedosekova, I.L.; Belyatsky, B.V. Age and substance sources of the Ilmeno-Vishnevogorsky alkaline complex (South Urals): Rb-Sr, $\mathrm{Sm}-\mathrm{Nd}, \mathrm{U}-\mathrm{Pb}$, and Lu-Hf isotope data. Dokl. Earth Sci. 2012, 446, 1071-1076. [CrossRef] 
38. Sturm, R. Imaging of growth banding of minerals using 2-stage sectioning: Application to accessory zircon. Micron 2004, 35, 681-684. [CrossRef] [PubMed]

39. Hinton, R.W.; Upton, B.G.J. The chemistry of zircon: Variations within and between large crystals from syenite and alkali basalt xenoliths. Geochim. Cosmochim. Acta 1991, 55, 3287-3302. [CrossRef]

40. Portnyagin, M.V.; Simakin, S.G.; Sobolev, A.V. Fluorine in primitive magmas of the Troodos Ophiolite complex, Cyprus: Analytical methods and main results. Geochem. Int. 2002, 40, 625-632.

41. Fedotova, A.A.; Bibikova, E.V.; Simakin, S.G. Ion-microprobe zircon geochemistry as an indicator of mineral genesis during geochronological studies. Geochem. Int. 2008, 46, 912-927. [CrossRef]

42. Dokukina, K.A.; Kaulina, T.V.; Konilov, A.N.; Mints, M.V.; Van, K.V.; Natapov, L.; Belousova, E.; Simakin, S.G.; Lepekhina, E.N. Archaean to Palaeoproterozoic high-grade evolution of the Belomorian eclogite province in the Gridino area, Fennoscandian Shield: Geochronological evidence. Gondwana Res. 2014, 25, 585-613. [CrossRef]

43. Jochum, K.P.; Dingwell, D.B.; Rocholl, A.; Stoll, B.; Hofmann, A.W.; Becker, S.; Besmehn, A.; Bessette, D.; Dietze, H.-J.; Dulski, P.; et al. The preparation and preliminary characterisation of eight geological MPI-DING reference glasses for in-situ microanalysis. Geostand. Newsl. 2000, 24, 87-133. [CrossRef]

44. Jochum, K.P.; Stoll, B.; Herwig, K.; Willbold, M.; Hofmiann, A.W.; Amini, M.; Aarburg, S.; Abouchami, W.; Hellebrand, E.; Mocek, B.; et al. MPI-DING reference glasses for in situ microanalysis: New reference values for element concentrations and isotope ratios. Geochem. Geophys. Geosyst. 2006, 7, 44. [CrossRef]

45. Rocholl, A.B.E.; Simon, K.; Jochum, K.P.; Bruhn, F.; Gehann, R.; Kramar, U.; Luecke, W.; Molzahn, M.; Pernicka, E.; Seufert, M.; et al. Chemical characterisation of NIST silicate glass certified reference material SRM 610 by ICP-MS, TIMS, LIMS, SSMS, INAA, AAS and PIXE. Geostand. Newsl. 1997, 21, 101-114. [CrossRef]

46. Bottazzi, P.; Ottolini, R.; Vannucci, A.; Zanetti, A. An accurate procedure for the quantification of rare earth elements in silicates. In SIMS IX Proceedings; Wileys: New York, NY, USA, 1994; pp. 927-930.

47. McDonough, W.F.; Sun, S.S. The composition of the Earth. Chem. Geol. 1995, 120, 223-253. [CrossRef]

48. Watson, E.B.; Wark, D.A.; Thomas, J.B. Crystallization thermometers for zircon and rutile. Contrib. Mineral. Petrol. 2006, 151, 413-433. [CrossRef]

49. Skublov, S.G.; Berezin, A.V.; Berezhnaya, N.G. General relations in the trace-element composition of zircons from eclogites with implications for the age of eclogites in the Belomorian Mobile Belt. Petrology 2012, 20, 427-449. [CrossRef]

50. Corfu, F.; Hanchar, J.M.; Hoskin, P.W.O.; Kinny, P. Atlas of zircon textures. Rev. Mineral. Geochem. 2003, 53, 469-500. [CrossRef]

51. Hoskin, P.W.O.; Schaltegger, U. The composition of zircon and igneous and metamorphic petrogenesis. Rev. Mineral. Geochem. 2003, 53, 27-62. [CrossRef]

52. Nedosekova, I.L.; Belousova, E.A.; Belyatsky, B.V. Hf isotopes and trace elements as indicators of zircon genesis in the evolution of the alkaline-carbonatite magmatic system (Il'meno-Vishnevogorskii Complex, Urals, Russia). Dokl. Earth Sci. 2015, 461, 384-389. [CrossRef]

53. Geisler, T.; Schaltegger, U.; Tomaschek, F. Re-equilibration of zircon in aqueous fluids and melts. Elements 2007, 3, 43-50. [CrossRef]

54. Gagnevin, D.; Daly, J.S.; Kronz, A. Zircon texture and chemical composition as a guide to magmatic processes and mixing in a granitic environment and coeval volcanic system. Contrib. Mineral. Petrol. 2010, 159, 579-596. [CrossRef]

55. Hoffman, J.F.; Long, J.V.P. Unusual sector zoning in Lewisian zircons. Mineral. Mag. 1984, 48, 513-517. [CrossRef]

56. Chamberlain, K.J.; Wilson, C.J.N.; Wooden, J.L.; Charlier, B.L.A.; Ireland, T.R. New perspectives on the Bishop Tuff from zircon textures, ages and trace elements. J. Petrol. 2014, 55, 395-426. [CrossRef]

57. Finch, R.J.; Hanchar, J.M.; Hoskin, P.W.O.; Burns, P.C. Rare-earth elements in synthetic zircon: Part 2. A singlecrystal X-ray study of xenotime substitution. Am. Mineral. 2001, 86, 681-689. [CrossRef]

58. Burnham, A.D.; Berry, A.J. Formation of Hadean granites by melting of igneous crust. Nat. Geosci. 2017, 10, 457-461. [CrossRef]

59. Skublov, S.G.; Marin, Y.B.; Galankina, O.L.; Simakin, S.G.; Myskova, T.M.; Astaf'ev, B.Y. The first discovery of abnormal (Y+REE)-enriched zircons in rocks of the Baltic Shield. Dokl. Earth Sci. 2011, 441, 1724-1731. [CrossRef]

60. Hofmann, A.E.; Valley, J.W.; Watson, E.B.; Cavosie, A.J.; Eiler, J.M. Sub-micron scale distributions of trace elements in zircon. Contrib. Mineral. Petrol. 2009, 158, 317-335. [CrossRef]

61. Hofmann, A.E.; Baker, M.B.; Eiler, J.M. Sub-micron-scale trace-element distributions in natural zircons of known provenance: Implications for Ti-in-zircon thermometry. Contrib. Mineral. Petrol. 2014, 168, 1057. [CrossRef] 